\title{
Application of the comet assay in human biomonitoring: An hCOMET perspective
}

\author{
Amaya Azqueta ${ }^{\mathrm{a}, \mathrm{b}}$, Carina Ladeira ${ }^{\mathrm{c}, \mathrm{d}}$, Lisa Giovannelli ${ }^{\mathrm{e}}$, Elisa Boutet-Robinet ${ }^{\mathrm{f}}$, \\ Stefano Bonassi ${ }^{\mathrm{g}, \mathrm{h}}$, Monica Neri ${ }^{\mathrm{g}}$, Goran Gajski ${ }^{\mathrm{i}}$, Susan Duthie ${ }^{\mathrm{j}}$, Cristian Del Bo ${ }^{\text {, }}$, \\ Patrizia Risok $^{\mathrm{k}}$, Gudrun Koppen ${ }^{\mathrm{l}}$, Nursen Basaran ${ }^{\mathrm{m}}$, Andrew Collins ${ }^{\mathrm{n}}$, Peter Møller ${ }^{\mathrm{o}, *}$ \\ a Department of Pharmacology and Toxicology, University of Navarra, C/Irunlarrea 1, 31009 Pamplona, Spain \\ b IdiSNA, Navarra Institute for Health Research, Spain \\ ${ }^{\mathrm{c}}$ HETRC - Health E Technology Research Center, ESTeSL - Escola Superior de Tecnologia da Saúde, Instituto Politécnico de Lisboa, Av. D. João II, lote 4.69.01, \\ Parque das Nações, 1990-096 Lisboa, Portugal \\ d Centro de Investigação e Estudos em Saúde Pública, Escola Nacional de Saúde Pública, ENSP, Universidade Nova de Lisboa, Portugal \\ e Dept. NEUROFARBA, Section Pharmacology and Toxicology, University of Florence, Florence, Italy \\ ${ }^{\mathrm{f}}$ Toxalim (Research Centre in Food Toxicology), Université de Toulouse, INRA, ENVT, INP-Purpan, UPS, Toulouse, France \\ $\mathrm{g}$ Unit of Clinical and Molecular Epidemiology IRCCS San Raffaele Pisana, Rome, Italy \\ ${ }^{\mathrm{h}}$ Department of Human Sciences and Quality of Life Promotion, San Raffaele University, Rome, Italy \\ ${ }^{i}$ Mutagenesis Unit, Institute for Medical Research and Occupational Health, Ksaverska Cesta 2, 10000 Zagreb, Croatia \\ ${ }^{\mathrm{j} S}$ School of Pharmacy and Life Sciences, The Robert Gordon University, Riverside East, Garthdee Road, Aberdeen AB10 7GJ, United Kingdom \\ ${ }^{\mathrm{k}}$ Università degli Studi di Milano, Department of Food, Environmental and Nutritional Sciences (DeFENS), Division of Human Nutrition, Via G. Celoria 2, \\ 20133 Milano, Italy \\ ${ }^{1}$ VITO Health, Flemish Institute for Technological Research (VITO), Mol, Belgium \\ ${ }^{\mathrm{m}}$ Hacettepe University, Faculty of Pharmacy, Department of Toxicology, 06100 Ankara, Turkey \\ n Department of Nutrition, Institute for Basic Medical Sciences, University of Oslo, Sognsvannsveien 9, 0372 Oslo, Norway \\ ${ }^{\circ}$ Department of Public Health, Section of Environmental Health, University of Copenhagen, DK-1014 Copenhagen K, Denmark
}

\section{A R T I C L E I N F O}

\section{Article history:}

Received 1 July 2019

Received in revised form 29 October 2019

Accepted 7 November 2019

Available online 9 November 2019

\section{Keywords:}

Comet assay

DNA damage

Fpg-sensitive sites

Human biomonitoring

Statistical analysis

\section{A B S T R A C T}

The comet assay is a well-accepted biomonitoring tool to examine the effect of dietary, lifestyle, environmental and occupational exposure on levels of DNA damage in human cells. With such a wide range of determinants for DNA damage levels, it becomes challenging to deal with confounding and certain factors are inter-related (e.g. poor nutritional intake may correlate with smoking status). This review describes the effect of intrinsic (i.e. sex, age, tobacco smoking, occupational exposure and obesity) and extrinsic (season, environmental exposures, diet, physical activity and alcohol consumption) factors on the level of DNA damage measured by the standard or enzyme-modified comet assay. Although each factor influences at least one comet assay endpoint, the collective evidence does not indicate single factors have a large impact. Thus, controlling for confounding may be necessary in a biomonitoring study, but none of the factors is strong enough to be regarded a priori as a confounder. Controlling for confounding in the comet assay requires a case-by-case approach. Inter-laboratory variation in levels of DNA damage and to some extent also reproducibility in biomonitoring studies are issues that have haunted the users of the comet assay for years. Procedures to collect specimens, and their storage, are not standardized. Likewise, statistical issues related to both sample-size calculation (before sampling of specimens) and statistical analysis of the results vary between studies. This review gives guidance to statistical analysis of the typically complex exposure, co-variate, and effect relationships in human biomonitoring studies.

\footnotetext{
* Corresponding author.
} 
Contents

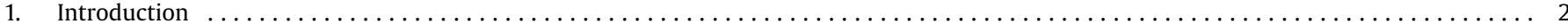

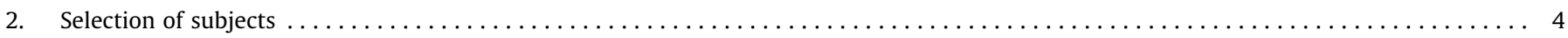

2.1. Confounders, effect modifiers and effect mediators in human biomonitoring studies $\ldots \ldots \ldots \ldots$

2.2. Types of factors that influence the level of DNA damage in humans $\ldots \ldots \ldots \ldots$

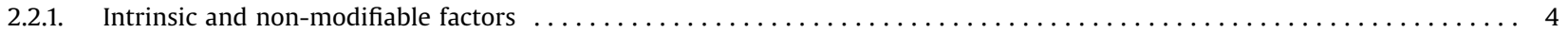

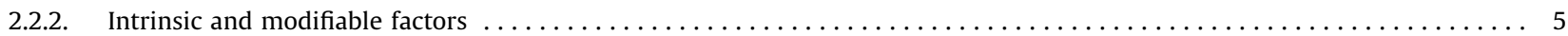

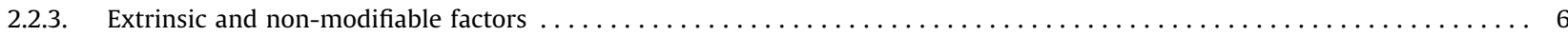

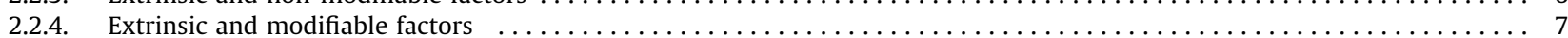

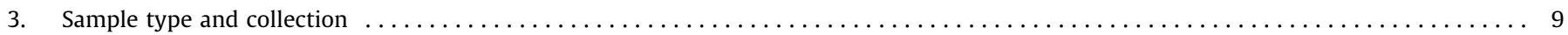

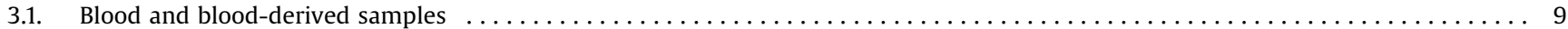

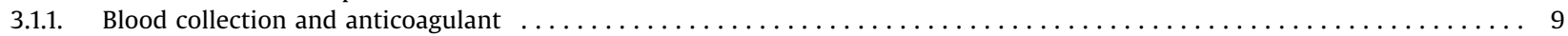

3.1.2. Different blood-derived preparations and cell types $\ldots \ldots \ldots \ldots \ldots$

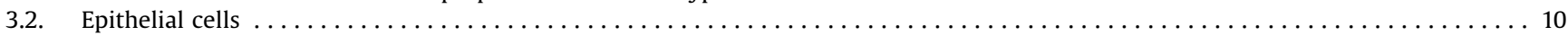

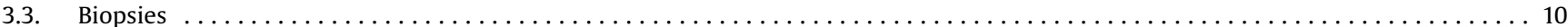

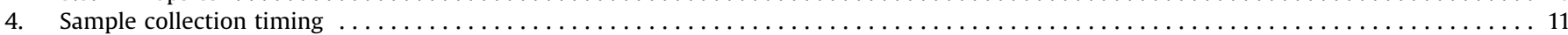

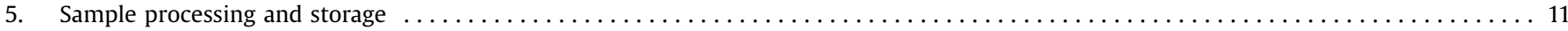

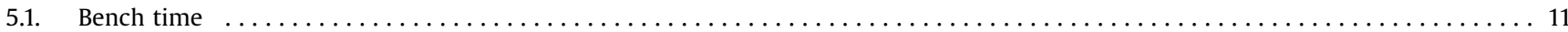

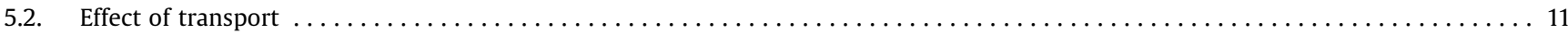

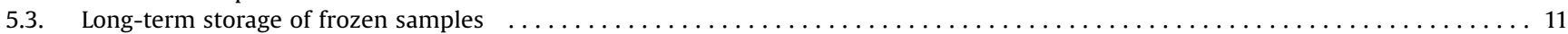

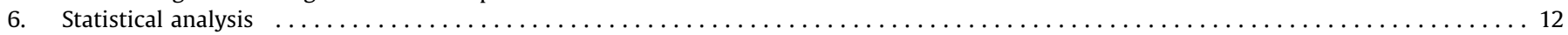

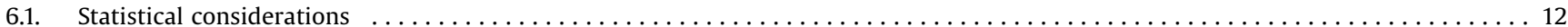

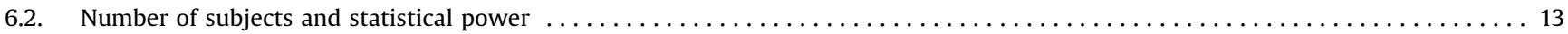

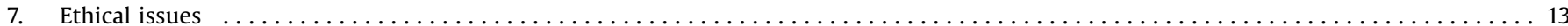

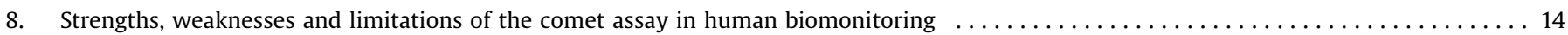

9. Application and interpretation of comet assay results in human biomonitoring studies $\ldots \ldots \ldots \ldots$

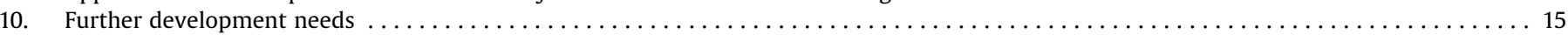

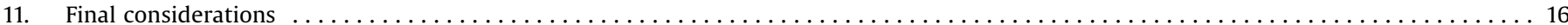

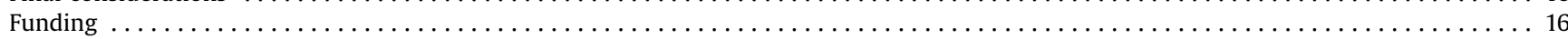

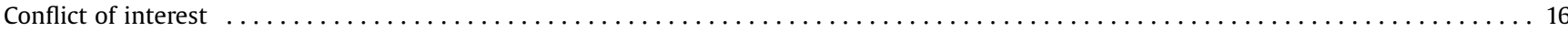

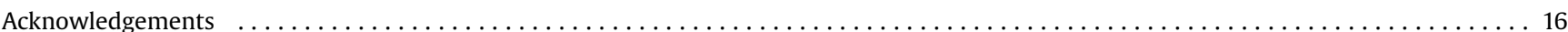

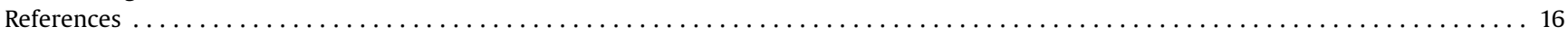

\section{Introduction}

Molecular epidemiology is based on the use of molecular biomarkers to identify or quantify disease effects or risk in epidemiological studies. Molecular epidemiology applied to humans has the advantage of being directly relevant, unlike animal or other experimental models that require extrapolation to humans. In epidemiological studies, biomarkers can be used in combination with health data to demonstrate an association between the body burden of pollutants and their health effects, or simply to test other research hypotheses $[1,2]$.

Biomarkers are typically measured in samples that can be obtained (relatively) non-invasively, which generally means blood or urine. DNA damage is recognized as a useful biomarker, by virtue of its role in carcinogenesis. Many lesions occur in the DNA of every cell each day, inflicted by natural or artificial exogenous radiation sources or genotoxic chemicals, or by endogenous exposure to e.g. reactive oxygen species, or as a result of errors in replication. But it should be borne in mind that almost all DNA damage is repaired, and that even if damage is present when DNA is replicated, it doesn't necessarily cause mutations. DNA damage should be regarded as a marker of exposure to DNA-damaging agents, and in that sense it reflects disease risk, but whether it can be seen as a predictive marker of individual cancer risk is debatable, in the absence of compelling evidence.

The comet assay is the most popular method for measuring DNA damage in human cells. Essentially it measures DNA breaks, through their ability to relax the supercoiling of DNA loops which can then extend under (alkaline) electrophoresis to form cometlike images; the relative intensity of tail DNA fluorescence indicates the frequency of breaks (Fig. 1). An additional step can be introduced, digesting the DNA with a lesion-specific enzyme, so that - for instance - oxidised bases are converted to breaks and the comet tail intensity increases. This modification is particularly useful in biomonitoring, as oxidative stress - and consequent DNA oxidation - is a feature of various kinds of exposure and many human diseases.

The aim of this article is to describe the key issues that are relevant in a biomonitoring study in which the comet assay is applied to measure DNA damage. We describe how different covariates may affect the outcome of the study. Some of the factors have been specifically assessed in systematic reviews, while others have not yet been assessed thoroughly. Some technical aspects related specifically to biomonitoring are also covered, such as sampling and storing of specimens, as well as statistical and ethical issues that should be addressed before and after the biomonitoring study. However, technical issues related specifically to variability in assay conditions and efforts to produce standard procedures have been reviewed elsewhere [4]. Inter-laboratory variation in DNA damage levels has been described since the early 2000s through ring-trials involving multiple laboratories [5-7]. Later ring-trials have shown reductions in inter-laboratory variation in DNA damage levels on cryopreserved cells by using standardization with reference standards and standardized comet assay procedures, although some variation persists even after such means of standardization [8-13].

In the context of the present review, exposure may refer to potentially hazardous agents of either physical (e.g. radiation) or chemical nature. Alternatively, an exposure may be positive in terms of health benefits - for example, certain dietary items and habits such as regular exercise. The present review encompasses studies that have assessed the effect of exposure on DNA damage. In this type of study, exposure (e.g. to a chemical agent) is the predictor and the level of DNA damage is the outcome. By design, the case-control study selects first the cases (and a matched control group) and then assesses the exposure. In that sense, the 


\section{Step 1 : From blood or other isolated cells to cells embedded in gel and deposit on slides}
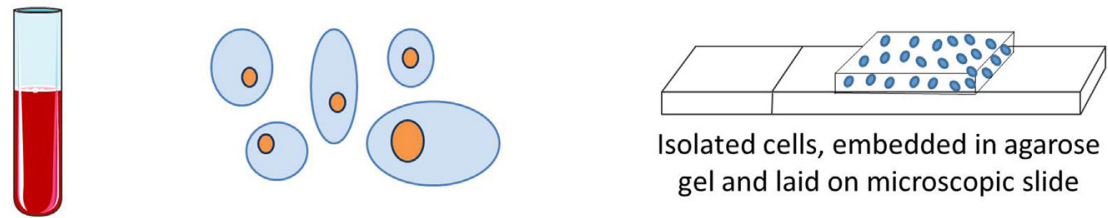

Isolated cells, embedded in agarose

gel and laid on microscopic slide

Step 2 : Alkaline lysis (membranes and soluble components removal)
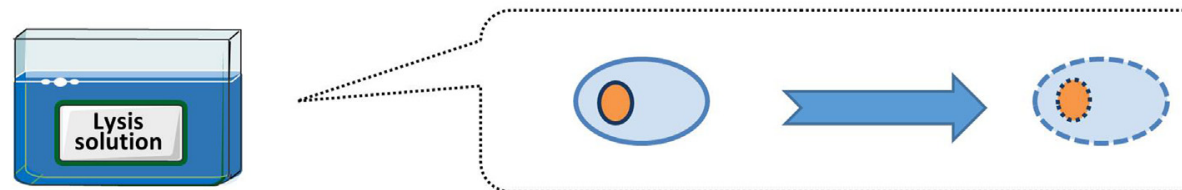

Step 3 : Electrophoresis (DNA denaturation, unwinding and migration)
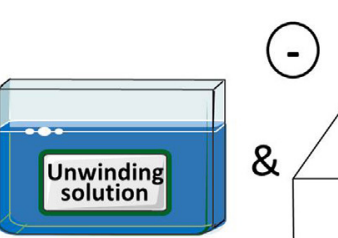

\&

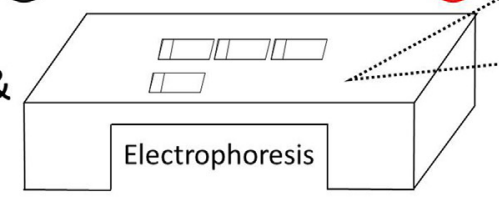

(+)
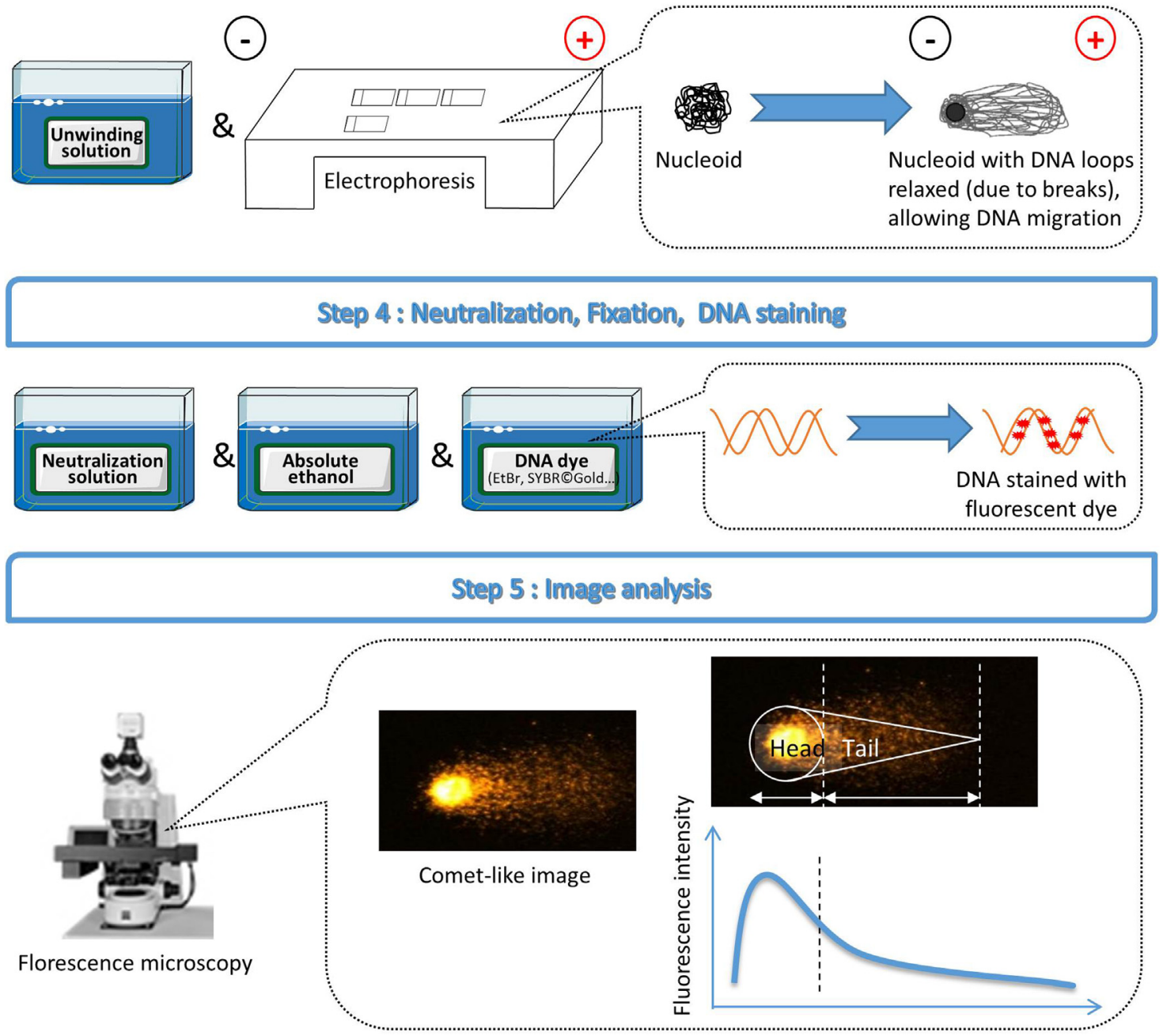

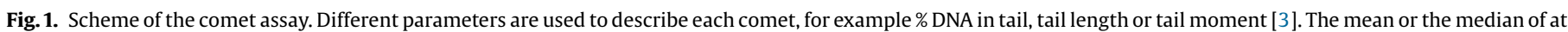
least 100 comets is normally used to describe each sample. 
level of DNA damage is the predictor, whereas the disease status is the outcome.

\section{Selection of subjects}

In human exposure studies, the predictor is either dichotomized into no exposure versus exposure (or low versus high exposure) or treated as a continuous variable. The outcome variable is usually treated as a continuous factor, although data reduction to categorical scale may occur in certain studies. The typical biomonitoring study assesses the effect of a certain predictor (here "exposure") on the outcome (here "DNA damage"). The trick is to obtain a gradient in the exposure, while at the same time avoiding selection of other factors that can influence the exposure-outcome relationship. This kind of disproportionate selection of certain factors in exposure groups is called confounding only if the factor is associated with both the predictor and the outcome. As the confounder per se is an independent risk factor for the outcome, it can be used ingeniously to gain better understanding of the complex relationship between exposure and outcome by for instance designing studies that utilize the information to test for interactions between the exposure and susceptibility factors. For example, age, sex and smoking are typically regarded as confounders, but a study can be carefully designed to assess the effect modification due to these factors by demonstrating that a certain exposure is only increasing the level of DNA damage in e.g. men, old people or smokers.

\subsection{Confounders, effect modifiers and effect mediators in human biomonitoring studies}

In molecular epidemiology, confounders, effect modifiers and effect mediators are factors that are used as co-variates in the statistical models. Below, age and sex are used as examples of factors that can be confounders, effect modifiers and effect mediators (further discussion of these variables in statistical modelling is provided in section 6. Statistical analysis). There is a wealth of information on effects of age and sex in biomonitoring studies because this information is frequently reported in the description of the subjects. However, only a few studies have been designed specifically to test effects of age and sex on DNA damage measured with the comet assay.

Fig. 2 describes different ways that effects of age and sex can be (or have been) assessed in study designs and statistical analyses. In these examples age and sex are regarded as endogenous factors, whereas "exposure" is an external factor. Age and sex may be regarded as confounders, i.e. they are associated with both the exposure (i.e. predictor) and level of DNA damage (i.e. outcome). As confounders, age and sex are associated with exposure if the selection of subjects according to the exposure status has also introduced an unequal balance in the age and sex distribution (e.g. those who are exposed are also older or predominantly males). This implies that information on age and sex is "irrelevant" in the sense that the statistical analysis adjusts for the effect of the confounders. It should be noted that control for confounding is a statistical solution to a study design problem and the confounder is considered $a$ priori to have an effect on the association between exposure and level of DNA damage. Other ways to prevent the effect of confounders are randomisation, restriction or matching of subjects. Age and sex may also be regarded as effect modifiers, i.e. the effect of an exposure will differ in strata of the dataset due to biological reasons (men and women, or old and young subjects, may have different responses to exposures). This is demonstrated by statistical analysis showing an interaction between the exposure and the modifier. Finally, the effects of age and sex may be mediated through exposures or life-style factors. In this

\section{A (confounders)}

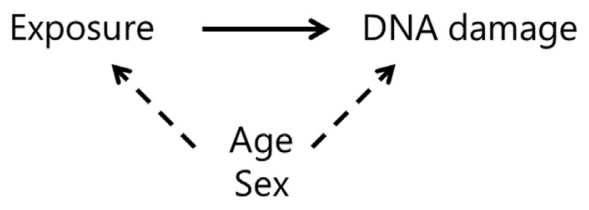

B (effect modifiers)

Age

Sex

Exposure

$\longrightarrow$ DNA damage

\section{C (effect mediators)}

Age

Sex
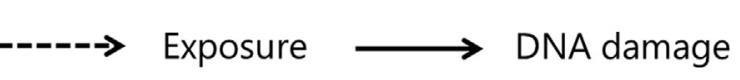

Fig. 2. Effect of age and sex on levels of DNA damage. As endogenous factors, age and sex may be regarded as classic confounders, i.e. they are associated with both the exposure and level of DNA damage (A). They may also affect the level of DNA damage through the exposure (B). As effect mediators, age and sex are observed to have an effect on DNA damage (e.g. in different strata of men and women, or old and young subjects), but this is mediated by underlying differences in exposures or lifestyle factors (C). Solid arrows refer to direct ("causal") relationships, whereas stippled arrows are associations ("perceived relationships"). The non-modifiable extrinsic factors are ubiquitous exposures (i.e. affecting whole populations rather than being relevant for certain individuals). These may be obtained by sampling on different days or in different seasons (i.e. seasonal variation).

case age and sex do not have a direct effect on the outcome (i.e. DNA damage). The apparent effect of age (and sex) on the outcome is explained by intermediate steps in the pathway. In this case (Fig. 2C), it is incorrect to consider age and sex as confounders as they are not independent risk factors for the outcome.

\subsection{Types of factors that influence the level of DNA damage in humans}

The planning of human biomonitoring studies entails a careful assessment of possible contributing factors to the level of DNA damage as well as within-group variation. This pertains not only to dealing with confounders (i.e. avoiding a systematic error), but also to random factors that might give rise to outliers in the results. The latter may be difficult to control as it could compete with a smooth selection of subjects or matching criteria between groups of exposed and controls. Table 1 describes the four different types of factors, which are described in further detail in the subsequent sections.

\subsubsection{Intrinsic and non-modifiable factors}

Sex and age are factors that subjects cannot change in the same way that dietary habits, physical activity or specific chemical exposures can be altered. The impact of age and sex on levels of DNA damage is well-known as illustrated by the several biomonitoring studies that restrict the inclusion of subjects to specific age groups or sex. The present review encompasses only studies that have assessed age and sex differences in DNA damage levels as a primary purpose of the investigation. These are predominantly cross-sectional studies. A detailed analysis of the effect of age and sex on DNA damage levels measured with the comet assay is reported elsewhere [14]. Various types of exposure studies have not been included because selection or matching of subjects in the reference group may have occurred. Cross-sectional studies are suitable for assessment of sex-specific differences in DNA damage levels, whereas they are not ideal for age-dependent differences because it is not possible to assess whether DNA 
Table 1

Types of factors that can affect the level of DNA damage in biomonitoring studies.

\begin{tabular}{|c|c|c|c|}
\hline Type of factor & Description & Examples & Controlling the influence \\
\hline \multicolumn{4}{|l|}{ Intrinsic (fixed) } \\
\hline Non-modifiable & $\begin{array}{l}\text { Factor that is fixed within each individual of the } \\
\text { study. Subjects do not control the factor }\end{array}$ & Age, sex, prescribed medication & $\begin{array}{l}\text { Can only be avoided by selection of } \\
\text { subjects or statistical adjustment }\end{array}$ \\
\hline Modifiable & $\begin{array}{l}\text { Factor that de facto is fixed within each } \\
\text { individual of the study. Subjects can change the } \\
\text { factor, but are not able or willing to do so }\end{array}$ & $\begin{array}{l}\text { Tobacco smoke, occupational exposure, obesity, } \\
\text { over the counter drugs ("pain killers") }\end{array}$ & $\begin{array}{l}\text { Can only be avoided by selection of } \\
\text { subjects (i.e. occupational exposure) or } \\
\text { statistical adjustment }\end{array}$ \\
\hline \multicolumn{4}{|c|}{ Extrinsic (random) } \\
\hline Non-modifiable & $\begin{array}{l}\text { Factor that is difficult to avoid and may vary } \\
\text { over time. The subjects do not control the } \\
\text { source of agent, although they may control their } \\
\text { own exposure }\end{array}$ & Air pollution, ambient temperature, sunlight & $\begin{array}{l}\text { Can be avoided by sampling in short } \\
\text { periods and having equal sampling of } \\
\text { exposed and controls on the same days }\end{array}$ \\
\hline Modifiable & $\begin{array}{l}\text { Factor that varies within each individual, } \\
\text { although it may fluctuate little due to personal } \\
\text { habits. Subjects control the exposure }\end{array}$ & Diet, physical activity, alcohol consumption & $\begin{array}{l}\text { Can be avoided by adherence to strict } \\
\text { protocols (e.g. abstaining from } \\
\text { exhaustive physical activity) }\end{array}$ \\
\hline
\end{tabular}

damage levels increase with age. Cross-sectional studies can merely be used to show that subjects with different ages have different levels of DNA damage. The review only includes results from studies that have assessed levels of DNA damage in white blood cells (WBCs), isolated as either leukocytes, peripheral blood mononuclear cells (PBMCs) or lymphocytes.

2.2.1.1. Age. Studies published before 2000 have mainly shown that age is not a strong predictor for the basal levels of DNA strand breaks in WBCs, which may be due to the use of non-optimal comet assay descriptors such as tail length [15]. A meta-analysis of studies published up to 2005 has shown a positive association between age and levels of DNA strand breaks in WBCs in studies that had used \%DNA in tail and visual classification as comet assay descriptors, whereas there was no difference in levels of Endonuclease III (EndoIII)- and Formamidopyrimidine DNA glycosylase (Fpg)-sensitive sites [16]. More recent studies, which specifically have assessed age-differences in levels of DNA strand breaks, have reported positive [17-23], null [24-28], or negative associations [29]. The discrepancy between studies may be related to multiple factors such as the age span, type of WBCs, analysis of fresh or frozen sample and the statistical analysis. The latter pertains to age treated as a categorical (i.e. age groups) or continuous (i.e. true age in years) variable. In addition, multivariate regression analysis seems to show little effect of age, which may be due to control for confounding or mediator effects. For instance, a large cross-sectional study of 992 subjects showed a positive association between age and levels of DNA damage in PBMCs $(P<0.05$, linear regression, not reported in the original article), but this was not significant in analysis adjusted for sex and a number of metabolic risk factors [28]. This indicates that the presumed effect of age was mediated by various life-style factors.

Only a few studies have assessed associations between age and oxidatively damaged DNA in WBCs. The reports have been mixed with studies showing positive association $[17,19,23]$ or no effect of age on levels of damage assessed with the Fpg- or hOGG1-modified comet assay $[20,25,28,30]$. Although mixed results have been reported, age should be considered as a confounder in studies that do not have statistical power to control for the effect of mediating life-style factors.

2.2.1.2. Sex. A systematic review of the literature published up to 2005 did not show a difference between levels of DNA strand breaks, EndoIII- and Fpg-sensitive sites in WBCs between women and men [16]. This is in agreement with several more recent studies that have shown no or equivocal difference between sexes in studies using multivariate analysis [21,23,25,26,28,31-34]. In fact, only a few studies have shown sex-differences in multivariate analysis; these reported a higher level of DNA strand breaks in women [35] or a higher level in men [27]. Studies without adjustment for potential confounders have either reported higher levels of DNA strand breaks in men [36], higher levels in women [24,32] or no effect of sex [37].

The relatively few studies on sex-dependent differences in levels of DNA damage in the Fpg-, hOGG1-, or EndoIII-modified comet assay have not revealed any difference between sexes $[28,31,32,36]$.

\subsubsection{Intrinsic and modifiable factors}

In theory, intrinsic and modifiable factors are changeable. Examples of such factors are tobacco smoking, daily use of pain killers and occupational exposures. Quitting smoking or changing job is possible, but it is not likely to happen as part of a human biomonitoring study. Thus, the effect of smoking or daily use of pain killers is typically avoided by standard practices for control of confounding. Likewise, exclusion of subjects from certain occupations or job titles (e.g. blue collar workers) is possible in molecular epidemiology.

2.2.2.1. Tobacco smoking. The effect of tobacco smoking on DNA damage has been thoroughly studied since tobacco contains a great variety of genotoxic/carcinogenic agents. Thus, smoking has also been considered to be a confounding factor.

Kassie et al. published a review in which they found that tobacco smoking causes an increase in DNA strand breaks in several human studies; however, the extent of the damage did not correlate with the number of cigarettes [38]. Some years later, Faust et al. showed that only 9 reports, out of 29 studies, found that tobacco smoking significantly increases the DNA strand breaks in lymphocytes, while 16 reports did not find such an association [39]. Moreover, the relationship between DNA damage and the number of cigarettes smoked per day was still not clear; some studies reported that smoking one or more cigarettes per day produces DNA damage in comparison with non-smokers, while others did not report any such effect even in those smoking 10 or more cigarettes per day. In the same paper it was reported that more than $55 \%$ of the studies specifically carried out to study the effect of tobacco smoking on DNA integrity using the comet assay did not find any association. Hoffmann et al. carried out a metaanalysis of 38 published studies and found a higher level of DNA strand breaks in smokers than in non-smokers [40]. However, the effect was very small when smoking was investigated as a potential confounding factor in occupational studies. In this direction, Collins et al. stated that smoking does not appear to be an 
important confounding factor in occupational studies [41]. It is worth mentioning that the design of a study in which smoking is considered just a confounding factor may not be powerful enough to detect differences between smokers and non-smokers.

The discrepancies observed in the different studies can be due to several factors such as the size of the sample (i.e. number of participants), the number of cigarettes smoked and the period over which they are smoked, the type of cigarettes (e.g. hand-rolled, with or without filter) and the brand. It has been noted that reports on the effect of smoking seemed to cluster in countries in the southern part of Europe and it is possible that brands of cigarettes with dark tobacco and high tar content are smoked more frequently in that region [15]. Kocygita et al. showed that the level of DNA strand breaks in mononuclear leukocytes were significantly higher in hand-rolled cigarette smokers than in filtercigarette smokers [42]. Both groups showed a significantly higher level of DNA strand breaks compared to the never smoker group. Overall, smokers present, if anything, a slightly higher level of DNA damage compared with non-smokers; but this cannot be detected if the statistical power is weak [39].

Another factor that may contribute to the discrepancies observed in different studies is passive smoking in the reference group, which is normally overlooked [39]. In this respect, Lam et al. carried out a study in elevator factory workers potentially exposed to benzene and observed that tobacco smoking, both active and passive at home, was significantly associated with DNA damage [43]. However, passive smoking in the work place did not affect DNA damage.

In all these studies, the standard alkaline comet assay was used; however, the Fpg-modified assay (or the use of another enzyme detecting oxidized bases) can be more appropriate to detect the DNA damage induced by tobacco smoking. Studies in which the effect of tobacco smoking is assessed by using the enzymemodified comet assay to measure oxidized lesions are scarce. Fracasso et al. showed a significant high level of DNA strand breaks in cells from active smokers compared with non-smokers or passive smokers [44]. The DNA damage observed when using Fpg was significantly higher than the level of strand breaks detected without using Fpg only in the group of active smokers. Surprisingly, the authors did not check for differences in the net Fpg-sensitive sites between groups. A review of 125 studies showed that smoking did not influence the level of Fpg- and EndoIII-sensitive sites [16]. It is worth mentioning that the objective of this study was to look for reference values for DNA lesions in blood cells and so not all the studies included smoking and non-smoking participants for the detection of Fpg- and EndoIII-sensitive sites.

Smokeless tobacco (electronic cigarettes) is also a source of genotoxic compounds. It should be emphasized that the effect of smokeless tobacco has not been assessed in human exposure studies. However, it has been demonstrated that this form also induces DNA strand breaks in peripheral blood samples [45]. Moreover, smokeless tobacco induces a significantly higher level of DNA strand breaks in lymphocytes than does regular tobacco smoking [46].

2.2.2.2. Occupational exposure. The effect of occupational exposure on DNA damage has been the subject of a large number of studies for reasons such as workers' security and for regulatory purposes, as well as for the investigation of biological, physical and chemical occupational hazards.

A wide range of chemicals have mutagenic and/or carcinogenic properties, that can act as environmental hazards, and may also be exposure factors in specific occupational settings. For instance, besides the risks to the general public, atmospheric pollution can be considered as an occupational health hazard to professional groups, such as traffic police or professional drivers working in urban areas $[47,48]$.
Biomonitoring of exposure to toxic chemicals in the workplace is a fundamental tool to evaluate human health risks, and to support strategies to establish a safe work environment. The comet assay has been used to detect and quantify DNA damage as a marker of exposure to genotoxic agents, in workers exposed to various occupational hazards including gases, chemicals and anticancer drugs. Its application in human safety and health risk monitoring is well established, particularly when assessing exposure to solvents, petrol by-products, heavy metals, mineral fibres and particulates. Several reviews summarize the wideranging use of the comet assay in occupational biomonitoring $[39,41,49]$. For instance, levels of Fpg-sites were significantly higher in WBCs and in buccal cells from "on the ground" airport workers, compared with controls selected from office workers at the same airport [50]. A similar finding was reported in a study of policeman in the Czech Republic [51]. Here, higher levels of both oxidised purines and pyrimidines (Fpg-and EndolII-sensitive sites) were measured in policemen working outdoors and exposed to traffic emissions when compared with colleagues working indoors. This effect was seasonal, and was only observed when air pollution, measured as particulate matter and polycyclic aromatic hydrocarbons (PAHs), was high. Oxidised DNA base damage correlated positively with recorded levels of environmental carcinogenic PAHs [51]. Genotoxic effects of occupational exposures to byproducts of petrol, heavy metals, organic solvents etc. have been reviewed [47].

2.2.2.3. Body Mass Index (BMI). The association between overweight/obesity (individuals with $\mathrm{BMI} \geq 25 \mathrm{~kg} / \mathrm{m}^{2}$ ) and DNA strand breaks or oxidatively damaged DNA damage is well documented [52]. In contrast, studies evaluating the influence of BMI in a eutrophic population (BMI $<25 \mathrm{~kg} / \mathrm{m}^{2}$ ) are scarce. Two studies $[53,54]$ have reported no correlation between normal BMI $\left(<25 \mathrm{~kg} / \mathrm{m}^{2}\right)$ and DNA strand breaks. Thus, BMI within the normal range does not appear to influence DNA damage in healthy individuals.

\subsubsection{Extrinsic and non-modifiable factors}

Extrinsic and non-modifiable factors are characterized by being ubiquitous and random exposures that are virtually impossible to control in a molecular epidemiology study. Air pollution levels, ambient temperature and sunlight are such factors that vary over short (e.g. day-to-day) and long periods (e.g. seasons of the year). In addition, they may display a high degree of co-variability. For instance, high solar radiation correlates with temperature and ozone levels. As sunlight exposure is highly dependent on the time of the year, these exposures have typically been investigated in the context of seasonal variation. Yet, air pollution is more complex as it may correlate inversely with temperature in some parts of the world (highest in the winter due to temperature inversion where cold air is trapped at ground level) and positively in warm parts (higher due to long-range dispersion of particles from wildland or forest fires).

2.2.3.1. Season. The impact of meteorology - and in a broader sense seasonal variations - on the level of base-line DNA damage measured via the comet assay, is studied in several papers. Topics relating to seasonal changes include variation in temperature, solar radiation (strength and duration), air pollution [ozone, particles, (semi-)volatile compounds], diet (antioxidants, cooking processes), allergy (pollen), physical exercise, time spent outdoors/in the sun, and wearing less skin-covering clothes. Recently, Gerić et al. [33] reported that sampling season and exposure to medical radiation were the two main variables in the results of comet assay tests on whole blood of 162 inhabitants of Zagreb (Croatia) recruited between 2008 and 2016. More 
specifically, this retrospective study showed that global sun radiation $\left(\mathrm{J} / \mathrm{cm}^{2}\right)$, temperature, and daily insolation $(\mathrm{h})$, were of influence. Their results confirmed most earlier cross-sectional and longitudinal studies. Increased DNA damage in warmer periods of the year was indeed also reported in studies in which healthy adults were sampled repetitively. In Greece, 40 non-smoking men, engaged in outdoor activities for $6 \mathrm{~h}$ each day during the summer, showed a higher level of DNA damage in mononuclear cells at the end of the summer (September) compared to the end of the winter (March) [55]. In Belgium, whole blood of 45 non-smoking office and laboratory workers was sampled four times, in all seasons of one year [56], and another group of 48 non-smoking office workers were sampled in winter and again in summer [57]. In both studies, DNA damage was correlated with the 8 -h-average ozone concentrations and the average outdoor temperature in the week before sampling. The latter studies were done to confirm the findings of a cross-sectional study in 200 adolescents (17-18y) participating in the Flemish Environment and Health Survey. In that study, both the whole blood comet assay results and urinary 8oxo-7,8-dihydro-2'-deoxyguanosine (8-oxodG) were affected by ozone concentrations and the average outdoor temperature, and by the hours of sunshine 3 days before sample collection [58]. The impact of solar radiation was intensively studied in another longitudinal study by Møller et al. [35]. Twenty-one office and laboratory workers were followed up about once a month, during a period of 14 months. DNA damage measured in the mononuclear cells was correlated to the average daily influx of sunlight during 36 days before blood sampling. The results suggested that sunlight penetrating the outer layer of the human epidermis (such as UVA and UVB) damaged DNA in PBMCs circulating in the vessels of the skin. Giovanelli et al. [25] observed in 79 office and laboratory workers sampled through the year a positive correlation of the individuals' DNA damage in mononuclear cells with the outdoor air temperature - and to a lesser extent with global solar radiation and air ozone levels. The frequency of DNA strand breaks showed a stronger seasonal trend as compared to the frequency of Fpg-sites, being higher in summer. UV radiation induces oxidative stress, and indeed specific photoproducts such as thymine dimers, that are converted into transient strand breaks upon DNA repair [25]. Interestingly, subjects with higher BMI $\left(\mathrm{BMI}>25 \mathrm{~kg} / \mathrm{m}^{2}\right)$ appeared to have higher sensitivity to outdoor temperature variations, perhaps because of a less efficient heat dispersion [25].

On the other hand, it should be noted that also a few studies reported DNA damage being higher in blood cells collected during winter time, in polluted areas of e.g. Czech Republic [59] and Poland [60]. Local heavier air pollution in the colder period, characterized by temperature inversion and increased fossil fuel burning, may explain this discrepancy.

Overall, higher sun radiation and outdoor temperatures seem to be important factors in explaining the observed higher DNA damage levels in warmer/sunnier seasons.

2.2.3.2. Environmental exposure. Anthropogenic pollution has become inherent to the modern environment. The rapid global increase in technogenic stress in the biosphere raises the question about possible consequences for biota, including humans, acknowledging that all forms of life are inter-connected and that human health is strongly linked to the ecosystem's health [61]. Environmental chemicals and contaminants are ubiquitous, occurring in water, air, food and soil. While some chemicals are short-lived in the environment and may elicit no harmful effects in humans, other chemicals bio-accumulate or persist for a long time in the environment or the human body due to frequent exposure, potentially leading to adverse health effects [62]. Various studies on comet assay endpoints in biomonitoring studies on environmental exposures have been reviewed elsewhere [63].
Among environmental exposures is air pollution, which is ubiquitous and difficult to assess without specific equipment, although the relevant literature describes both personal exposures as well as modelled data based on stationary monitoring station recordings of ambient air pollution components. Air pollution, primarily particulate matter from combustion processes, adversely affects human health, increasing both mortality and morbidity. The comet assay is being employed to establish the impact of air pollutants on DNA damage in different population and occupational groups (reviewed in Møller and Loft [64]).

Temporal and spatial variations in air pollution levels are very often used to obtain exposure gradients. In a study of people in Benin either living/working near to persistently heavy traffic, or in a rural environment, Fpg-sensitive sites in PBMCs increased according to location and personal exposure to benzene as a specific component in fuel as indicated by urinary S-phenylmercapturic acid (S-PMA), a biomarker of benzene exposure [65]. Examples of studies that have employed gradients in air pollution levels come from studies in Denmark where personal exposure to levels of ultrafine particles from traffic correlated with levels of Fpg-sensitive sites in PBMCs $[66,67]$. The same research group has reported that traffic-related air pollution in a chamber was associated with higher levels of DNA damage in PBMCs [68], whereas short-term exposure to even a high concentration of diesel exhaust $\left(276 \mu \mathrm{g} / \mathrm{m}^{3}\right.$ for $3 \mathrm{~h}$ ) had no effect on DNA strand breaks or oxidatively damaged DNA in PBMCs [69]. Wood smoke is another important source of particulate matter, which is increasingly relevant as an environmental exposure with the increasing number of wildfires. Nevertheless, recent studies have shown mixed results - in chamber studies after short-term exposure $[70,71]$, or a one-week stay in a reconstructed Viking Age house with an indoor open fire [72], or in wildfire firefighters [73]. Likewise, a recent chamber study showed that $5.5 \mathrm{~h}$ exposure to household dust $\left(275 \mu \mathrm{g} / \mathrm{m}^{3}\right)$ did not alter levels of DNA strand breaks or oxidatively generated purine lesions in PBMCs [74]. The collective results indicate that traffic-related air pollution has a greater effect on the types of DNA lesions that are detected by the comet assay, compared with either wood smoke or dusts in household air. Also, gases such as carbon monoxide, ozone, nitrogen oxides, sulphur dioxide are examples of atmospheric pollutants that may lead to DNA damage and pose a serious threat to human health. Other applications of the comet assay regarding air pollution include exposure to formaldehyde and nitrogen dioxide in children living near a chipboard factory in Italy [75], PAHs in the air in children in Mexico [76], and pollution containing cadmium, lead, dichlorodiphenyldichloroethylene (p,p'-DDE), hexachlorobenzene, polychlorinated biphenyls (PCBs) and benzene in residents in Flanders [77].

\subsubsection{Extrinsic and modifiable factors}

In daily life people are in contact with many agents with the potential to provoke or prevent mutagenic and carcinogenic effects [78]. In comparison with intrinsic and non-modifiable factors such as age and sex, these exposures are not constant as they may display day-to-day variation and may be avoided (e.g. by subjects disliking the taste of dietary items) or actively sought for personal reasons (e.g. regular physical activity). Such factors might not cause confounding in a study as they may be highly individualized. For instance, ingestion of certain dietary items may be associated with genotoxicity, but there are few subjects with the relevant dietary habit in the source population. Thus, in the rare event of such a person entering a biomonitoring study, the biomarker value is likely to be regarded as an outlier.

2.2.4.1. Dietary exposure to toxic substances. There are relatively few studies that have assessed the influence of dietary genotoxic 
compounds in humans. An example of such an investigation comes from a biomonitoring study on aflatoxin exposure in the Gambia [79]. However, genotoxic effects of food mutagens have been investigated in cell cultures or animal models. An interesting example of a hybrid approach is a study where the comet assay was used to examine the negative influence of foods such as red meat, using cultured human colon cells exposed to human faecal waters [80].

2.2.4.2. Dietary macro-and micro-components. The comet assay is used extensively in human biomonitoring to assess the impact of whole foods (e.g. fruits and vegetables), specific nutrients (phytophenols and antioxidants) and supplements (e.g. folic acid, selenium, carotenoids) on biomarkers of DNA stability, including DNA strand breakage, and altered DNA bases (e.g. oxidation, alkylation and misincorporated uracil).

The ability of whole foods to protect against DNA damage has been tested extensively using the comet assay in observational studies. Historically, a high intake of various foodstuffs, such as fruits, vegetables and juices, that are rich in antioxidant vitamins and phytophenols, has been found to be positively associated with low levels of endogenous DNA strand breakage and oxidised DNA bases, and to protect against ex vivo generation of DNA damage (reviewed in Dusinska and Collins [81]). A recent cross-sectional study focused on habitual ingestion of fish, vegetables, fruits, salads, whole-grain bread and potatoes in a relatively large study of subjects $(n=973)$ in a high-income area of Copenhagen, Denmark [82]. This showed an inverse association between intake of fish and levels of Fpg-sensitive sites in women after adjustment for various other life-style factors. The same inverse association was also seen in univariate analysis in men, but it was not robust in adjusted analysis, whereas salad intake was inversely associated with levels of Fpg-sensitive sites in adjusted analysis. Although this is merely a cross-sectional study, it points especially to the intake of fish as a food category that may have a protective effect on levels of oxidatively damaged DNA in humans. It is an observation that needs to be confirmed in a well-designed intervention trial.

Diet and dietary components have been shown to play an important role in the protection against DNA damage in welldesigned intervention studies. The comet assay is used widely to investigate the influence of intervention with specific nutrients (primarily as supplements) and whole foods on biomarkers of genomic stability, including DNA strand breakage and base damage. In a ground-breaking study testing the antioxidant hypothesis of DNA damage and cancer, supplementing male smokers and non-smokers with vitamin C (100 mg), vitamin E $(280 \mathrm{mg}$ ) and $\beta$-carotene $(25 \mathrm{mg}$ ) daily for 20 weeks, substantially decreased endogenous DNA pyrimidine oxidation (measured using EndoIII) and significantly increased resistance to hydrogenperoxide-induced DNA strand breakage ex vivo [83].

Several medium- to long-term intervention studies have shown reduced levels of DNA lesions after ingestion of bioactive-rich foods and/or food bioactives [84-89]. However, the protective effects have also been detected after the intake of single portions of bioactive-rich foods and/or components [90-93]. This modulation seems to be dependent on several factors such as the type of food product(s), the bioavailability of the constituent(s) and the length of time between food consumption and DNA damage evaluation.

There have been few studies evaluating the acute effect of bioactive-rich foods on the levels of oxidized purines and background DNA strand breaks, with conflicting results. Bakuradze and co-workers [94] found that the intake of $200 \mathrm{~mL}$ of coffee, every $2 \mathrm{~h}$ until $8 \mathrm{~h}$, significantly decreased background DNA strand breaks levels in healthy volunteers. Brivida et al. [95] showed that the consumption of $1000 \mathrm{~g}$ of organically or conventionally grown apples, providing 308 and $321 \mu \mathrm{g} / \mathrm{g}$ fresh weight of total polyphenols respectively, decreased the levels of EndoIII-sensitive sites at $24 \mathrm{~h}$ after consumption. In contrast, Del Bo' and colleagues $[91,96]$ reported no significant effect on DNA strand break levels and Fpg-sensitive sites following acute consumption of blueberries in smoking and non-smoking volunteers.

Folate deficiency very specifically results in the misincorporation of the RNA-associated base uracil into DNA, consequently inducing DNA single and double strand breakage and chromosomal damage [97]. One modification of the comet assay has allowed uracil explicitly to be measured in human lymphocyte DNA [98]. Here, nucleoids, post-lysis, are incubated with the bacterial DNA repair enzyme uracil DNA glycosylase, revealing misincorporated uracil in the DNA. In a randomised double-blind placebocontrolled intervention, mis-incorporated uracil, measured using the alkaline comet assay and uracil DNA glycosylase, was significantly decreased in healthy men and women supplemented with $1.2 \mathrm{mg}$ folic acid each day for 3 months [99]. Moreover, it was also found that improved folate status (red cell, lymphocyte and plasma folate) strongly correlated with the reduction in DNA uracil mis-incorporation, highlighting the value of this modified comet assay in human biomonitoring [99].

A special application of the comet assay in dietary intervention studies has been the challenge assay where the resistance to ex vivo induced DNA damage by an oxidizing agent such as $\mathrm{H}_{2} \mathrm{O}_{2}$ has been measured. Protection has been reported following either an antioxidant cocktail of $\beta$-carotene, vitamin $C$ and vitamin $E$ [83] or more complex food sources such as carrot juice [100], tomato extract [101], kiwi fruits [102,103], broccoli [104,105], wild blueberry [106] and hazelnuts [107]. However, some studies reported no effect [108-110].

On the whole, bioactives should be recognized as potential confounding factors (see 2.2.3). This could represent a critical aspect within biomonitoring studies in which the evaluation of DNA damage by the comet assay is performed in different subjects exposed to diverse conditions. On the other hand, evidence is very scarce or non-existent concerning the impact on DNA damage of the consumption of meals differing in macro and micronutrients or the impact of supplements and their possible antagonistic and/or synergistic effects. The dietary intervention studies have been instrumental for research on specific macro- or micronutrients. However, they also tend to be somewhat excessive in the exposure. For instance, it will be difficult to find a person who daily eats $300 \mathrm{~g}$ blueberry purée or drinks $500 \mathrm{~mL}$ of kiwifruit juice $[91,93]$. The results from the dietary intervention studies may not be directly applicable for biomonitoring guidelines. In that respect, it should be emphasized that certain intervention studies have selected specific groups of the population to avoid confounding, and the sampling of cells has been optimized to detect the effect on DNA damage levels. Generalization of the observations from dietary intervention studies to the general population is uncertain. Conservatively, it is recommended that the evaluation of DNA damage is performed on samples of blood that have been collected on a standardized time schedule (e.g. after an overnight fast). Such standardization of factors related to diet and overall behaviour could help to minimize potential bias and improve the comparison of data deriving from different studies.

2.2.4.3. Physical activity. The comet assay has been used to investigate the potential induction of DNA damage after physical exercise since it is known that this practice causes oxidative stress [111]. DNA instability has been assessed in two different scenarios; in volunteers just after performing exhaustive physical activity or in volunteers who regularly perform physical activity.

Hartmann et al. tested the effect of a short run with increasing speed in 3 healthy volunteers and found an increase in DNA strand breaks in WBCs after the exercise [112]. The effect was seen after 
$6 \mathrm{~h}$ and it reached a maximum after $24 \mathrm{~h}$. DNA strand break levels were back to basal level after $72 \mathrm{~h}$. In the same study volunteers were subjected to a $45 \mathrm{~min}$ run at fixed speed to ensure aerobic metabolism, and the aforementioned effect was not seen [112]. The same authors demonstrated how vitamin E supplements decreased the DNA damage detected after $24 \mathrm{~h}$ of running on a treadmill until exhaustion [113]. They also showed that although trained and untrained volunteers exhibit a significant increase in the DNA damage of WBCs after exhaustive exercise, the increase was higher in untrained than in trained volunteers, suggesting an adaptation process [114]. Some years later, the same group performed a study in which they measured DNA damage in 6 athletes after a short-distance triathlon competition [115]. No effect was seen after the exercise; however a significant increase in DNA strand breaks was seen after 1-5 days in a biphasic pattern, with a small peak after $24 \mathrm{~h}$ and a larger one after 3 days. After 5 days, the basal level was not reached. However, the Fpg-modified comet assay did not reveal any extra damage. Likewise, there were unaltered levels of Fpg-sensitive sites and DNA strand breaks after a triathlon race, whereas the levels of EndoIII-sensitive sites were slightly increased at day 5 post-exercise [116]. A shorter bout of exhaustive bicycle exercise also did not change the levels of DNA strand breaks, Fpg-sensitive sites and EndoIII-sensitive site when performed in normoxia, whereas there were increased levels of DNA strand breaks immediately after exercise in high altitude hypoxia [117]. The increase in DNA damage after a bout of exercise has also been seen in forty older adults and in young soccer players after performing physical activity $[118,119]$. The young soccer players did not recover the basal DNA damage level even after 45 days [11]. Esteves et al. showed how the level of DNA oxidation damage in dancers, measured using Fpg, significantly increased after the dancing season [120]. However, the pre-season level was lower than in a control group. In this case, the levels of DNA strand breaks were not significantly affected.

The effect of regular exercise on the basal level of DNA damage in volunteers who exercise regularly has also been tested. While some authors report a lower level of DNA damage in lymphocytes of people who perform regular exercise [19,120-122], others did not find any association between exercise and the level of DNA damage [37,123] and some even report a higher level [124]. In this last study, even the $\mathrm{H}_{2} \mathrm{O}_{2}$ resistance was lower in sportsmen doing regular exercise, namely rugby players. In a recent study, the DNA damage level found in lymphocytes was lower in the recreational group compared to sedentary and lifelong amateur endurance practice volunteers [125].

To sum up it is quite clear that DNA damage increases after a bout of exhaustive exercise but the effect is not so clear in people who regularly take part in sport. An adaptive response was proposed in the case of low levels of DNA damage found in sportsmen [114].

2.2.4.4. Alcohol consumption. Acetaldehyde, the first metabolite in alcohol degradation, induces crosslinks and forms adducts with DNA and proteins [126,127]. There are several human studies in which the effect of alcohol consumption on the DNA damage has been studied using the comet assay.

Studies performed in alcoholics showed that they present higher levels of DNA damage in blood cells than do control subjects $[128,129]$. A positive correlation between alcohol intake and DNA damage has also been found in healthy individuals [27,130]. In contrast, Pool-Zobel and co-workers showed that DNA damage in rectal cells and lymphocytes, both DNA strand breaks and EndoIIIsensitive sites, was lower in male patients with alcohol abuse than in controls [131]. However, the number of participants, especially of the controls, was very low. Løhr et al. showed a significant positive association between alcohol intake and Fpg-sensitive sites in men but not in women [28]. The study was performed in 1019 subjects (aged 18-93) with the aim of studying the association of the levels of oxidatively damaged DNA and metabolic risk factors. Milić et al. did not find any increase in DNA damage in blood cells of alcohol consumers compared to non-consumers [132].

Alcohol consumption has been included as co-variate in the statistical analysis (i.e. as a possible confounder) in several studies, showing conflicting results. Some studies have reported a positive association between alcohol consumptions and DNA damage in blood cells $[133,134]$. A lack of association between DNA damage in blood cells and alcohol consumption has been reported by several authors [135-139]. Moreover, the lack of association has also been reported in exfoliated buccal cells [140].

Conflicting results can be due to the amount or the type of alcohol consumed; many of the reports do not give this information. Also, the sample size can have a great impact on the reliability of results. Moderate alcohol consumption, especially wine drinking could also have beneficial effects on redox status and DNA stability. It has been hypothesized that regular consumption of moderate doses of wine could provide health benefits. Wine's beneficial effect has been attributed principally to its non-alcoholic portion, which has antioxidant properties [141143]. An important issue to mention is that acetaldehyde induces DNA crosslinks, which can indeed decrease DNA migration. This is a factor to take into account when interpreting results, and could be a cause of conflicting results.

\section{Sample type and collection}

Sample collection is an important step and variability needs to be reduced as much as possible in order to obtain reliable data. Each laboratory should set up standard collection procedures and adhere strictly to them throughout the experiments.

In particular, it is necessary to define the following during the planning phase: subject conditions at collection time (e.g. fasted or not for blood samples, timing during the day if relevant, etc.); collection modality; choice of anticoagulant for blood, cell maintenance medium for all cells, enzymatic treatment where required; temperature and maximal extent of bench time (from sample collection to comet slide preparation); container and tube types; sample identification and documentation.

\subsection{Blood and blood-derived samples}

\subsubsection{Blood collection and anticoagulant}

Blood is obviously the most suitable and widely used tissue in human biomonitoring, due both to the low invasiveness of the withdrawal and to the abundance of information available on blood composition deriving from routine clinical biochemistry. The majority of studies use venepuncture but blood collection with a lancet could also be suitable as only a small volume of blood is necessary and mean baseline levels of damage from pin-prick samples and samples collected by venepuncture have been described to be similar [144].

The choice of anticoagulant may be crucial, as an increase in plasma DNA (from damaged leukocytes) has been reported to occur beyond $6 \mathrm{~h}$ in samples collected with citrate or heparin [145]. However, whether the choice of anticoagulant has any effect on comet assay results has not been established, and EDTA, citrate and heparin are all currently used.

\subsubsection{Different blood-derived preparations and cell types}

Among blood cells, the most used so far are gradient-isolated mononuclear leukocytes, often referred to as "lymphocytes", although in this fraction monocytes are also present in a significant proportion (about $1 / 4$ of the mononuclear fraction). The reason to 
focus on this subpopulation, besides the fact that it is more homogeneous than total leukocytes, is that PBMCs circulate throughout the body, have a reasonably long life span, and can therefore serve as sentinel cells in biomonitoring studies [146]. However, it has been shown that the procedure of PBMC isolation is not devoid of consequences on the basal levels of DNA damage: strand breaks are increased in gradient-isolated PBMCs compared to non-isolated, although oxidized bases measured as Fpgsensitive sites are not modified [147]. Bausinger and Speit reported that radiation- and alkylating agent-induced DNA damage is decreased in PBMCs compared to whole blood [148]. The response to ex vivo oxidative stress is also much higher in PBMCs than in whole blood [147]. This is actually an advantage of the isolated cells, especially in intervention studies where antioxidant/protective treatments are tested. In fact, the basal levels of DNA damage in blood cells are usually very low in healthy volunteers, and it would be difficult to measure a further decrease of these levels; instead, it is possible in this context to evaluate the protection from ex vivo-induced DNA damage, reflecting the antioxidant status [91,93].

An increasing number of human biomonitoring studies with the comet assay have used whole blood, thus avoiding the separation procedure [149-151]. In this case only nucleated cells, i.e. the leukocytes can be studied. Using whole blood is simpler, but since it contains the complete spectrum of leukocytes, results obtained with whole blood and with isolated PBMCs may not be comparable. The possibility has been described to score separately polymorphonuclear and mononuclear cells in whole blood slides, but the procedure is time consuming, and the visual distinction can be subjected to variability originating from both different operators and different employed assay conditions [147].

In biobanks (see section 5.3 Long-term storage of frozen samples), blood is usually stored either as such or as buffy coat, and the possibility to work with these samples can give access to large epidemiological retrospective studies. For this reason, buffy coat has recently received attention from researchers interested in the use of the comet assay in human biomonitoring. The preparation of the buffy coat involves a simple centrifugation of whole blood, producing a layer enriched in concentrated leukocytes at the top of the red cells) that can consequently be aspirated in a small volume. In the end, a blood preparation with 5-6 times concentrated leukocytes is obtained, in which the WBCs still benefit from the protective effects of plasma and red blood cell antioxidant power. Indeed, unpublished studies indicate that the basal levels of DNA damage measured in buffy coat preparations are not different from those measured in whole blood, supporting the hypothesis that this preparation can be equally useful. An advantage of buffy coat compared to whole blood is that it is often available in biobanks [152]. Still, it needs to be verified whether the presence of free radical-producing neutrophils can modify the basal levels of damage with time, particularly upon long-term storage, given the presence of protective red blood cells [153].

Although most of the studies use leukocytes from whole blood, there is increasing interest in assessing primary DNA damage in salivary leukocytes especially in terms of air pollution impact. These cells, directly exposed to air passage through the mouth, represent the target cells of this exposure and in that way are more appropriate than blood cells for the evaluation of its effects. Moreover, they are easy to retrieve, especially in children, using a simple and non-invasive method, which allows obtaining a substantial sample size. Despite that, some problems have been identified, such as the number of cells retrieved per sample, the interference caused by the buccal epithelial cells on the comet images, and the consequent time-consuming analysis of the slides [154-156].

\subsection{Epithelial cells}

Epithelial cells amenable for human biomonitoring are exfoliated cells from easily-reached epithelia, such as those in mouth and nose, which are also first-contact sites for environmental pollutants. Cell collection might be relatively easy, but the number of cells obtained is usually quite low, although this is generally not a problem with the comet assay, which can be run with very small numbers of cells. Another important issue with exfoliated cells is their physiological state (dead, necrotic/ apoptotic, damaged or healthy) that can influence the measured levels of DNA damage: thus, the assessment of cell viability appears to be particularly important before proceeding to the measurement of DNA damage. Furthermore, in some cases there might be a need to separate cell aggregates through enzymatic digestion. For all these reasons, usually these cells display higher basal DNA damage levels than blood or cultured cells: however, it has been shown that it is still possible to detect increases in DNA damage in association with different environmental stressors. Sampling protocols, sample storage and preparation for the most used cell types, and the adaptations of the method for each specific context, have been reviewed by Rojas et al. [157].

The use of exfoliated buccal cells has been proposed and repeatedly used for genotoxicity testing in human biomonitoring both with the micronucleus test and with the comet assay [158]. These cells can be simply obtained by mouth wash or oral mucosa brushing. Increases in DNA damage in these cells have been reported in occupational settings [159], and in association with lifestyle and environmental factors such as tobacco smoking, pollutants in drinking water [160], or radiations [161]. It has also been proposed that these cells can be a useful tool in nutritional studies [158].

Nasal cells are obtained by gently brushing the turbinate epithelium $[162,163]$. This cell type has an obvious advantage over circulating leukocytes in studies on inhalation exposure to airborne pollutants in the ambient air or workplace. In some cases of air pollution exposure, the results obtained in nasal cells were different from those obtained in peripheral leukocytes, indicating that these epithelial cells can be a better marker of damage, at least for some types of exposure or pathology [164]. Although this type of cell is very relevant for respiratory exposure, the brushing procedure, although minimally invasive, is reported to be unpleasant for the donor, and probably for this reason it has not gained as much popularity as it might have.

Tear duct epithelial cells are also exposed to environmental pollutants, and can be simply recovered from tears. Up to date, only one study has used them in human biomonitoring [165], finding a DNA-damaging effect of urban atmospheres with high ozone concentrations.

An interesting new application of the comet assay involves cells from surgically removed tissues from the human eye, including corneal epithelium and endothelium, lens capsule, iris and retinal pigment epithelium [166]. This cell type is interesting due to the direct contact of airborne DNA damaging agents with the epithelial cells of the eye, although the technique needs to be further developed and validated.

Exfoliated bladder cells can be recovered from urine and used for routine urine cytology, and they have also been used for DNA damage measurement with the comet assay. In rubber workers at risk of bladder cancer, comet assay results showed a better concordance with cytoscopy than with urine cytology [167].

\subsection{Biopsies}

The comet assay is routinely used to detect DNA damage on tissue samples in genotoxicology studies. In fact, the OECD guideline for the in vivo comet assay (TG 489) refers specifically 
to the use of tissue samples in animal models [168]. However, this application of the comet assay is rarely used in research projects on healthy humans. A rare example is the use of the comet assay, including the enzyme-modified comet assay, on muscle biopsies from healthy human volunteers who were exposed to high altitude hypoxia [169]. In clinical contexts, cells from biopsies, such as colon biopsies have also been used [131].

\section{Sample collection timing}

Sampling conditions such as sampling time can be an important factor in the comet assay because DNA damage can increase, if environmental conditions are not optimal. It is suggested that seasonal variations and sampling time play a more important role in the comet assay than in other cytogenetic assays such as micronuclei and chromosomal aberrations [170]. In biomonitoring studies, it is advisable to take blood samples at the same time from fasting subjects (usually in the morning hours) and to transport them in cool conditions. However, it is more important to collect samples from all exposed and control subjects at the same time of the day to reduce the possibility of time variations that can influence the results [171]. If a study extends over more than a year, samples should be taken in the same season in each year. When blood was sampled in the warmer period of the year, comet assay descriptors were found to be higher $[33,81]$.

\section{Sample processing and storage}

\subsection{Bench time}

Ideally, the comet assay is performed immediately following peripheral blood collection. However, in large human studies or studies requiring sampling far from laboratories, these optimal conditions are not feasible. In this context, storage conditions of whole blood should be optimised before performing the comet assay. It can also be a good strategy to cryopreserve samples in studies with repeated sampling from the same subjects such as dietary interventions or environmental exposures (e.g. air pollution). The reason is that the exposure contrast may produce less response (i.e. delta-value between exposure and control period) than the inter-day assay variation.

In some cases, samples can be processed within several hours, and the comet assay is performed on fresh cells. Koppen et al. reported a weak decline of DNA strand breaks with increasing storage time on the bench, for samples processed within $6 \mathrm{~h}$ of sampling. Turbulence and shearing during blood drawing might have induced mechanical damage upon sampling, being restored during the time after collection [172]. The same was also described by Dusinska and Collins [81] in PBMCs processed within $4 \mathrm{~h}$ after sampling. On the other hand, in both studies, an increase in Fpgsensitive sites was observed when blood samples were stored at room temperature during those time periods.

Anderson et al. reported that storage for up to 4 days at either room temperature or $4{ }^{\circ} \mathrm{C}$ did not induce any DNA strand breaks in human whole blood measured with the comet assay [173]. Similar conclusions that samples can be stored for up to 4 days at both room temperature and $4{ }^{\circ} \mathrm{C}$ without affecting the level of DNA strand breaks were found in the study from Collins [174]. Chang and Hu have also shown that DNA strand breakage in whole blood was stable up to $4 \mathrm{~h}$ at $4{ }^{\circ} \mathrm{C}$ after isolation [175]. In contrast, the study from Narayanan et al. described an increase in DNA damage when human blood was stored at room temperature or $4{ }^{\circ} \mathrm{C}$ for $24 \mathrm{~h}$, with a further increase after $48 \mathrm{~h}$ of storage [176]. More recently, Al-Salmani and co-workers also reported that overnight storage $(12 \mathrm{~h})$ of a large volume of blood $(5 \mathrm{~mL})$ at $4{ }^{\circ} \mathrm{C}$ tended to induce an increase of damage [144].
The temperature, volume and duration of blood storage appear to be crucial parameters to consider when processing samples for the comet assay. Altogether, these studies suggest that some components of whole blood can be considered as preservative agents but these effects are limited, and temperature, volume and time dependent. Moreover, some components and reactions can also alter the DNA, e.g. lysis of red blood cells and presence of neutrophils that can undergo an oxidative burst.

Due to inconsistent results from all these studies, short time storage (less than $4 \mathrm{~h}$ ), at $4{ }^{\circ} \mathrm{C}$ or room temperature is advised in order to avoid any DNA damage between whole blood collection and processing for the comet assay.

\subsection{Effect of transport}

Shipping of whole blood, kept in an isolated package, to keep the blood at room temperature (ca. $15-35^{\circ} \mathrm{C}$ ) is a feasible option based on the results of Anderson et al. [173] and Koppen et al. [172]. They showed that whole blood samples stored at room temperature up to respectively 4 and 3 days, did not show an increase in DNA strand breaks.

\subsection{Long-term storage of frozen samples}

Storage of samples represents a common practice in biomonitoring studies where, for logistic reasons, the comet assay is not generally performed on fresh material. In fact, the majority of human data on DNA damage are derived from analyses performed on cryopreserved cells, but in some cases, there is no mention of the storage process (e.g. method of cryopreservation, duration of storage). Both whole blood and isolated PBMCs can be frozen and stored at $-80^{\circ} \mathrm{C}$ or in liquid nitrogen. However, the freezing method, the medium used for cryopreservation, storage conditions and the thawing process, could all represent potential critical factors affecting cell viability, DNA damage levels, and cellular responses (such as DNA repair). At the moment, there are various approaches to sample cryopreservation. For whole blood, some researchers suggest flash-freezing small volumes (max250 $\mu \mathrm{L}$ ) of samples in order to avoid crystal formation [144]; others report that diluting whole blood with an equal volume of cell culture medium containing $20 \%$ DMSO prevents damage during freezing [177]. Regarding PBMCs, some studies suggest suspending cells in PBS or medium with $10 \%$ DMSO [41], while others report suspending cells in $50 \%$ foetal bovine serum, $40 \%$ medium and 10 \% DMSO [13]. The number of cells stored could be an important factor to be standardized. For example, to improve cell viability it is recommended to freeze PBMCs at concentrations of $\leq 3 \times 10^{7}$ cells/ $\mathrm{mL}$ [178]. For optimal cryoprotection of PBMCs, slow freezing is recommended (ideally $1{ }^{\circ} \mathrm{C} / \mathrm{min}$ ) using a commercial' Mr Frosty' freezing unit with isopropyl alcohol, or a well-insulated expanded polystyrene box.

A different approach was used by Zhang et al. where DNA was successfully preserved in freeze-dried somatic cells using trehalose as protectant and storage at or below $4{ }^{\circ} \mathrm{C}$ [179]. Furthermore, solid tissues for later comet assay analysis are typically stored via snap freezing in liquid nitrogen, keeping the tissue deep-frozen until they are rapidly homogenized and embedded in agarose [180].

Regarding the effect of long-term storage on DNA damage, the information available is limited and insufficient to exclude the existence of a significant impact. Several studies have reported an increase in DNA damage with the freeze-thaw process compared with that found in different fresh cells [181-183], while others reported no effect on the levels of DNA damage [144,184,185]. These conflicting results could be attributed to the time and storage temperature of cryopreservation used. For example, Del Bo' et al. documented an increase in the levels of background DNA 
damage and oxidized purines after 1 year of PBMC storage at $-80^{\circ} \mathrm{C}$ compared with fresh samples [186]. In contrast, Duthie and co-workers showed that the levels of oxidized pyrimidines, oxidized purines and uracil were similar in both freshly isolated and frozen lymphocytes [185], implying that the DNA damage that is already present in the DNA of fresh cells is maintained throughout the isolation and storage procedure. However, the samples were stored only for 2 months. Pu and colleagues showed that the storage of lymphocytes at $-80^{\circ} \mathrm{C}$ up to 28 days did not affect the DNA damage, while the storage at $-20^{\circ} \mathrm{C}$ for 14 and 28 days increased both DNA strand breaks and oxidatively damaged DNA compared to fresh cells [181]. Regarding the use of whole blood, the same authors found no significant changes in samples stored at $-20^{\circ} \mathrm{C}$ for 1 day or 7 days, or at $-80^{\circ} \mathrm{C}$ for up to 28 days compared to fresh samples, while they documented significant increases in both DNA strand breaks and DNA base oxidation in whole blood samples stored at $-20^{\circ} \mathrm{C}$ for 14 or 28 days [181]. AkorDewu and colleagues showed that freezing whole blood at $-80^{\circ} \mathrm{C}$ is a suitable method for storing samples, at least for periods of a few weeks or months, for subsequent analysis of DNA strand breaks and Fpg-sensitive sites [184]. However, the ability of $\mathrm{H}_{2} \mathrm{O}_{2}$ to induce DNA strand breaks is severely attenuated in whole blood compared with freshly isolated or frozen PBMCs. Leukocytes isolated from frozen blood showed higher basal levels of damage (strand breaks/alkali-labile sites) and an abnormal resistance to damage by $\mathrm{H}_{2} \mathrm{O}_{2}$ compared to PBMCs isolated from fresh blood [184], though after repeated washing (to remove residual erythrocyte components) their sensitivity to $\mathrm{H}_{2} \mathrm{O}_{2}$ resembled that of PBMCs.

The ultimate in long-term storage is the biobank. Biobanks are repositories storing biosamples, in $-80^{\circ} \mathrm{C}$ freezers or in or above liquid nitrogen, generally for research and/or clinical purposes. They represent a potentially valuable resource for DNA damage analysis, but only if appropriate freezing and storage conditions have been followed. Cryopreservation protocols are available for PBMCs [185,187,188] as well as whole blood [144,152,172]. Protocols and try-outs for preservation of DNA in buffy coat samples were recently tested $[152,153,189]$.

Assuming an appropriate preservation method was used, any type of sample from a biobank can be used for assessment of DNA damage using the comet assay. European biobanks can be identified through the biobank directory of the European Research Infrastructure Consortium: Biobanking and BioMolecular resources Research Infrastructure (BBMRI-ERIC) (http://www.bbmri-eric. $\mathrm{eu} /$ ). The platform describes the nature, origin, destination, and the biobank lifecycle of each biospecimen (time of collection, preregistration, receipt, processing, quality control, storage conditions, request for use, retrieval, and distribution). Experience with the comet assay on samples stored for extended periods is limited, and careful evaluation of results will be needed, at least until optimal conditions for cryopreservation and for reducing adverse effects of storage have been defined.

\section{Statistical analysis}

Due to the epidemiological nature of biomonitoring studies, a critical evaluation of statistical methods for the analysis of comet assay results should take into consideration the study design and the control of external variables. Therefore, critical issues include a proper estimation of the sample size, the detection and control of bias during study design, and strategies to control for confounding and to search for effect modification. As a matter of fact, the question to be answered by a biomonitoring study is not if an effect of the condition under evaluation is present or not ( $p$ value), but how large is this effect (relative to the unexposed controls), and how reliable is this estimate (confidence interval).

\subsection{Statistical considerations}

The comet assay used in biomonitoring studies shares some basic features with other biomarkers used for the measurement of early pathogenetic events, such as high technical variability and poor agreement between scorers, the departure from normality, the need to define a fixed number of cells to be scored, etc. On the other hand, this biomarker is characterized by a number of peculiar features. For example, several endpoints can be evaluated for the same physical outcome (i.e. migration of DNA in the agarose gel). Even when statistical analyses include only the four most frequently used endpoints (i.e. tail intensity, tail length, tail moment and damage index), a problem of multiple comparison may originate in many cases, because more than one endpoint is often measured in the same study.

The possible approaches for design and analysis of experimental studies using the comet assay have been described in several papers [190]. Much less literature is available for the use of this biomarker in biomonitoring studies. A critical evaluation of the most used statistical approaches has been published by Collins et al. [41]. The most common statistical procedures entailed univariate parametric and non-parametric techniques, while regression analysis was carried out in nearly one third of the 50 studies reviewed. Standard approaches used in epidemiologic studies, such as controlling of confounding and testing for interaction, were seldom applied. The use of the p-value to compare study groups was common, while quantitative measures of effect (point and interval) were used occasionally.

To describe the endpoints of the comet assay, measures of central tendency are commonly computed, usually the arithmetic mean and the median. This is generally reasonable when the sample size is large and the frequency distribution is unimodal or not markedly asymmetric. In this case, for descriptive purposes only, reporting arithmetic mean and standard deviation is correct. However, if these conditions are violated, the range of minimum/ maximum values and some significant percentiles, for instance 25 th, 50-th (median) and 75-th, should be used instead, as they are less sensitive to the above-mentioned violations [191].

With appropriate transformations, it is possible to approximate the distribution of various endpoints of the comet assay to the normal distribution, which exhibits important statistical properties. In many cases it is suitable to use the original value logarithm to improve the distribution normality [192]. Whenever the data distribution does not differ from a normal distribution, the levels of DNA damage can be compared between two groups by applying the Student's $t$-test. When the analysis is aimed at comparing three or more exposure groups, a natural extension of the $t$-test is the analysis of variance (ANOVA) [192]. When the sample size is small, and/or logtransformation does not work, a non-parametric approach is preferred. The Mann-Whitney test is an efficient non-parametric approach to compare two unpaired groups. If the data are paired or matched, then the Wilcoxon matched pairs test provides a valid alternative to the paired Student's t-test. The Kruskal-Wallis test can be applied as a non-parametric alternative to the ANOVA.

In observational investigations of human populations, individuals may differ in several conditions, including lifestyle, exposure to occupational and environmental toxic agents, or genomic profile. If the distribution of conditions affecting DNA damage is unbalanced in the study groups, the association under study can be confounded by the action of these factors. Effect modification is another important feature, since it identifies subpopulations that respond differentially to the condition under study. While the confounding effect of external variables can be taken into account in the statistical analysis of data, the presence of effect modification can be merely identified and separate analyses for relevant subpopulations should be performed. The most straightforward, 
efficient and powerful way of reducing confounding and assessing effect modification is statistical modelling [41,191]. With the use of statistical modelling it is possible to quantify the presence of a relationship between the outcome and all considered variables (categorical or continuous) to generate estimates of association adjusted for the effect of confounders, and to assess the presence of effect modification. In the field of biomarkers, most statistical models are fitted to data to assess whether a variable predicts an outcome, and they are generally known as regression models [193].

In general, to build up regression model, it is necessary to define the way through which the linear predictor $(L P)$ acts on the mean response $(\mu)$, and to identify a probability distribution for the response variable $(Y)$, essential to estimate the parameters included in the regression equation using the maximum likelihood $(M L)$ method. An extensive discussion on the probability distribution of data from biomonitoring studies using the comet assay can be found in Lovell and Omori [190], confirming that in most cases a normal or a log normal distribution can be assumed.

In its simplest form, that is the multiple normal (additive) regression, the coefficient of regression expresses the variation of $\mu$ per each unit increase of each linear predictor when the other predictors are held constant. The effect of the variables analysed on the level of DNA damage is measured in the same unit as the outcome, e.g. $\mu \mathrm{m}$ for the tail length or \% for tail intensity. This feature may be misleading in the presence of a large interlaboratory variability since, for example, an increase of $2 \mu \mathrm{m}$ in tail length may be a small variation in some laboratories while in others it may represent an important change. The shift to log transformed data to approximate the normal distribution, implies two important modelling characteristics, i.e. expected values $(\mu)$ are non-negative (due to the antilog function), and measures of effect are ratios (multiplicative scale) and not differences (additive scale). Thus, as is shown in the following equation, the measure of the association between exposure and outcome is represented by the ratio of expected mean values $(M R)$ of exposed $(E=1)$ to unexposed $(E=0)$ individuals, once confounding is removed:

$\log \left(\mu_{E=1}\right)-\log \left(\mu_{E=0}\right)=\log \left(\frac{\mu_{E=1}}{\mu_{E=0}}\right)=\beta_{1} \rightarrow \frac{\mu_{E=1}}{\mu_{E=0}}=e^{\beta_{1}}=M R$

Recently, traditional approaches to statistical analysis of data from biomonitoring studies have been implemented with advanced techniques, in many cases derived from the analysis of clinical trials. For instance, multicentre biomonitoring studies may exhibit a hierarchical structure with multiple levels: if several laboratories are involved in different areas, individual DNA damage levels represent the first level of the hierarchy, while laboratories and areas represent the following levels. This type of data organization implicitly assumes that each level is nested in the higher level and represents a homogeneous cluster of observations. The purpose of the multilevel regression modelling [194] is to verify whether the hierarchical structure affects the measurements of interest. Ignoring the multilevel structure of data means that an important component of within-cluster correlation may be missed, underestimating the standard errors of the parameters evaluated. In this framework, two classes of regression parameters can be estimated using the multilevel regression. The first class is represented by the fixed effects parameters $(\beta)$ which return the mean effect of covariates (exposure in particular) within or across levels. The second class are defined as the random effects (RES) parameters and reflect the degree of heterogeneity within each level.

\subsection{Number of subjects and statistical power}

Sample size evaluation is a preliminary step of study design. The study population size should be large enough to reach statistical significance if the observed effect (i.e. level of DNA damage in exposed $v s$. unexposed subjects) is as large as expected or even larger. Since the level of statistical power and the chance of the type 1 error are quite standardized, i.e. $80 \%$ and $\alpha<0.05$, the definition of the sample size is essentially based on the magnitude and the variability of the expected effect [191]. Under mild statistical conditions (normality and homoscedastic data assumption), sample size calculation can be derived from the following formula [192]

$N>2\left(S \frac{z_{\alpha}+z_{\beta}}{\delta}\right)^{2}$

where:

- $z_{\alpha}$ and $z_{\beta}$ are the standardized normal deviates corresponding to $\alpha$ and $\beta$ error rates [e.g. 1.96 (corresponding to $z_{\alpha}=5 \%$ ) and 0.84 (corresponding to $z_{\beta}=80 \%$ )];

- $\delta=\bar{y}_{1}-\bar{y}_{0}$ is the anticipated difference in mean DNA damage between exposed and unexposed subjects respectively;

- $S$ = standard deviation obtained from pilot studies or from the literature;

- $N$ is the number of subjects in each group.

There are several user-friendly statistical packages available in the internet for the optimal sample size calculation. The presence of several possible endpoints, a peculiarity of the comet assay, is not a major concern, since all of them follow approximately a normal distribution (even if within a fixed interval, in the case of the damage index).

The choice of the reference value is a little more complicated. This value is the mean DNA damage that would be observed in the study population if the study factor were not present. Given the large inter-laboratory variability of the assay results, it may be unreliable to use reference values from studies performed in other laboratories or from the literature. It seems advisable to use data from previous studies conducted in the same laboratory, or even better from a pilot study performed using the same conditions as in the final study.

In some cases, it may be difficult to have a reliable estimate of the standard error, and the equation could be resolved for the ratio of the anticipated mean difference between exposed and unexposed to its variability $(\delta / S)$. Obviously, the study size will grow larger as the expected difference between the means of unexposed and exposed individuals is smaller or its variability is larger.

\section{Ethical issues}

Ethical issues regarding biomonitoring studies conducted with the comet assay are not different from ethics requirements typical of other molecular epidemiology studies, because the reasons that justify conducting biomonitoring studies with this assay are similar to those for using other tests. The debate on ethical issues in molecular epidemiological research dates from the beginning of this discipline [195]. Often these studies do not provide direct and immediate benefits to participants; however, they may have scientific and public interest, as long as they can measure the effects of an intervention or improve our knowledge of occupational or environmental risks, allowing the implementation of preventive measures.

A desirable, distinctive feature of the comet assay is the possibility of using a variety of non-invasive procedures for biosample collection, which supports a highly favourable balance between health benefits and risks and involves minimal interference with the participants. Sampling methods, nature and quantity 
of the biosamples may have both ethical and practical implications, particularly when dealing with vulnerable populations [196,197].

Guidelines exist about sample collection and biorepository management, and they generally include substantive chapters on ethical issues (e.g. [198-200], inspired by the principles of the Declaration of Helsinki [201]). These guidelines are constantly updated and modified, as the scientific and social debate progresses, while technical evolution poses new ethical and legal questions and challenges. In addition, ethical and data protection rules may vary greatly across laboratories and countries, an aspect that should be attentively considered when planning multicentric studies and international collaborations [198]. The need for a more harmonized and consistent socio-ethical and legal approach in human biomonitoring studies has been pinpointed some time ago, at least at the European level, with the aim of guaranteeing more equality in the protection of individual rights and increasing data comparability [202]. The European Cooperation in Science and Technology (COST) is a funding organization for research networks - called COST Actions. The network on human biomonitoring using the comet assay (hCOMET) strives to improve the quality of the technique in studies on human exposures and diseases. Preparation of specific guidelines with Standard Operating Procedures for human biomonitoring studies with the comet assay is one of the goals of hCOMET. The guidelines will cover all major aspects of planning and execution of this kind of research, including ethical issues (http://www.hcomet.org).

Ethical issues are governed by law in most countries. A study cannot start before submission to the concerned ethics committee (EC) at an institutional, regional or national level for "consideration, comment, guidance and approval" [201]. The committee must be transparent, independent and qualified.

The ECs generally include experts from several fields (e.g. lawyers, statisticians, toxicologists, psychologists) and evaluate the study design, sample collection procedures, questionnaires and informed consent documents. In addition, insurance arrangements may be required when the specimen collection can pose a risk to the participants (e.g. blood samples), and many countries also require clearance from the agencies which oversee data safety [203].

Informed consent has a central role for the respect of autonomy. It must be obtained before collecting any biological sample or clinical, social and occupational data from the subjects participating in the study. Comprehensible information must be given to all participants on the nature and implications of the study, on potential risks, discomforts and benefits for them. It must be clearly stated that they enter voluntarily in the study and they have the right to withdraw with no consequence at any moment. Incentives or compensations, when permitted by local law, must be described in detail. Particular attention must be paid when vulnerable subjects are concerned, as is the case of adults with intellectual disabilities or children [196].

Future studies are being mentioned with increasing frequency in the informed consent forms, due to the rapid technological progress in sample analysis, the diffusion of large biorepositories, the drive towards analyses of pooled data and the spread of epidemiological study designs such as historical cohorts and nested case-control studies. Maximizing the amount of information which is obtainable from limited samples, while minimizing the burden imposed to participants is per se an ethical issue, and allows saving of time and resources. Data sharing and material transfer represent a major asset of modern molecular epidemiology; however they need to be governed by specific transfer agreements. The subjects should have the possibility to agree or not, freely and consciously, to the use of their biological data for future study questions and by other researchers in unforeseeable, unspecified assays or follow up studies [203].
Protection of privacy and confidentiality of data stored or processed for research purposes is the object of increasing attention by the regulatory bodies. Any biological material should be coded, and the identities of subjects participating in the study should be protected in databases through safe coding, encrypting or anonymizing procedures. Proper data management must be secured, and specific databases, not available to outsiders, may be used for storage of their personal data [200]. However, a strictly anonymous collection of samples may be almost useless for molecular epidemiological research, which is based on linkage of laboratory results with other personal data of the subjects (e.g. occupation, health-related conditions, lifestyle, genetic profile, clinical follow up [204]).

Finally, each subject has the right to decide whether to be informed or not of the results of the study, and this should be explicitly mentioned in the informed consent form. In human biomonitoring studies communication is preferably given at group level: information on individual risk might generate stress or stigmatization, and in any case the ability of the comet assay to assess individual risk is still far from being clear, when extrapolated from the research context. The development of a communication plan is recommended and may be of great help, particularly in case of reporting of unexpected results with unknown clinical significance [205].

\section{Strengths, weaknesses and limitations of the comet assay in human biomonitoring}

As a biomarker assay in human studies, the comet assay has these advantages:

- - It can be applied to blood samples, which are obtained in a relatively non-invasive way; it is assumed that blood cells, circulating throughout the body, reflect the overall body burden of DNA damage;

- It is simple and economical to perform;

- It can be performed on samples stored frozen (though whether there is a limit on the period of storage needs to be established);

- It requires only a small number of cells (though for measurement of DNA repair, more material is needed);

- There is no need to stimulate the cells to divide;

- Other tissues can be used under certain circumstances (for example, tissue obtained after surgery for cancer);

- The measurement of oxidation damage to DNA using enzymes (i.e. Fpg or EndoIII) is relevant not just to cancer but to other diseases involving oxidative stress, whether as a cause or an effect.

There are some disadvantages and limitations:

- Circulating WBCs are not 'target' cells for carcinogenesis in solid tissues;

- Preparation of single cells is needed in the case of solid tissues, which may increase the background level of DNA damage;

- The assay shows rather high levels of variability, especially when comparing results between laboratories;

- Some forms of damage are not detected with the comet assay (bulky adducts), or cannot be distinguished (double- and singlestrand breaks), or require complicated modifications (interstrand cross-links);

- DNA damage measured in human cells is a marker of exposure to damaging agents, but there is no evidence as yet that it can be used as a predictive marker of cancer risk;

- The assay is saturated (i.e. the \% tail DNA approaches 100) at a level of damage of a few thousand lesions per cell, and so its 
detection range is less than that of other assays. However, this range easily covers physiologically relevant levels of damage (levels that human cells can survive).

- Results with Fpg should be interpreted with caution; Fpg detects some alkylated as well as oxidised bases.

- The EndoIII-modified comet assay does not have an assay control, which implies that the results on this type of DNA damage are somewhat uncertain. Efforts should be made to develop a reliable positive assay control for the EndoIII-modified comet assay.

\section{Application and interpretation of comet assay results in human biomonitoring studies}

The comet assay is often used in biomonitoring studies on environmental, occupational and dietary exposures as a biomarker of exposure to genotoxic agents (or protective agents in the case of phytochemicals). This includes cross-sectional, panel (i.e. repeated sampling from the same subjects) and controlled exposures studies (e.g. intervention trials). Considering the diversity of study designs, it is not meaningful to list specific recommendations for enhancing the application and interpretation of comet assay results, although certain issues are noteworthy. The study design, way of controlling confounding factors, collection of samples and the choice of statistical analysis must be assessed on a case-by-case basis. Using one type of study design will affect the way confounding can be controlled and the choice of statistical analysis. As a biomarker of exposure to genotoxic agents, there are certain considerations relevant to users of the comet assay:

- Dealing with confounders is a challenging effort. A "one size fits all" solution does not exist as there are different ways to deal with confounders, depending on the sample population. It should also be stressed that control for confounding is not a "the more the merrier" situation. Very strong control of confounding might introduce attenuation bias due to over-matching of exposed and unexposed subjects. At present there is not concrete knowledge on which factors are consistent and strong determinants for the level of DNA damage and which have just been associated with DNA damage in certain studies. There is relatively large inter-study variation in the effect of potential confounders as well as environmental, occupational and dietary exposures. The inter-laboratory variation may be due to differences in sampling of cells, comet assay procedures (i.e. differences in baseline levels of DNA damage), populations (i.e. susceptibility to DNA damage by the exposure), and control for confounding factors in the study design or statistical analysis. It is important to note that control for presumed confounders by restriction might yield results that cannot be generalized. For instance, if the presumed confounder is actually an effect modifier, there will be inter-study variation in the effect of the exposure between two studies that have assessed the association in the different strata of the general population.

- The sample collection depends on feasibilities and economic issues (e.g. it may only be possible to sample at one time point which may have been selected to analyse other biomarkers with narrower window of effect). Likewise, the effect of cryopreservation and differences in DNA damage between subpopulations of leukocytes are issues that would be easy to standardize (e.g. by recommending the use of cryopreserved PBMCs), but would require adoption by all researchers.

- The proper statistical analysis is determined by the study design and control for confounding or effect modifiers. General recommendations on the statistical analysis cannot be made in the same way as for instance studies on animals or cells.
However, biomonitoring studies are rarely so simple that Student's t-test, Mann-Whitney $U$ test or simple correlation tests are appropriate statistical methods.

- The use of internal assay controls is crucial in biomonitoring studies. Assay controls should always be analysed in studies that use samples directly in the comet assay without cryopreservation because they provide information about the assay variation over time. In principle, it is not necessary to include assay control in controlled exposure studies on cryopreserved samples if they are analysed in the same comet assay run; but it increases the validity of the study and in the enzymemodified comet assay it provides important information about the activity of the enzyme. However, it is important to note that inclusion of assay controls does not reduce the inter-laboratory variation in basal levels of DNA damage or differences in susceptibility due to effect modifiers.

\section{Further development needs}

This review has revealed many aspects of the comet assay where further development is necessary or desirable. Variability between laboratories would be greatly reduced if a standard protocol were adhered to; with this in mind, standard operating procedures are being devised within the hCOMET COST Action. The use of reference standards - i.e. cells with a known amount of DNA damage - should be mandatory in biomonitoring studies, serving two purposes; first, as an internal laboratory check on the performance of the comet assay on the day, and second, to facilitate comparisons between laboratories ('normalising' all data so that they are expressed as functions of the reference standard value). Ideally, reference standards could be provided by a central laboratory. There is a strong case for calibrating the assay (using Xor gamma-irradiated cells, since the frequency of breaks induced per Gy is known), so that all results could be expressed in terms of breaks per $10^{9} \mathrm{Da}$, or per $10^{6}$ base-pairs, for example.

While modifications of the comet assay to measure altered DNA bases (oxidised purines, oxidised pyrimidines, and uracil) are now used routinely to assess the impact of occupational and environmental exposures on genomic stability, new variations are being developed to further improve the specificity and effectiveness of the assay in human biomonitoring. A modified comet assay using specific restriction endonucleases (HpaII, HhaI and MspI) has been developed with the aim of measuring the global methylation status of DNA in single human cells [206,207]. Aberrant DNA methylation, both hypo- and hyper-methylation, is strongly linked with carcinogenesis in vivo and in humans. Adapting the comet assay to specifically detect changes in DNA methylation patterns in human subjects will undoubtedly advance understanding of how epigenetics influences human cancer risk.

DNA repair is an important facet of individual response to DNA damage effects, whether it is intrinsically determined, or inducible by exposure. As a biomonitoring tool it is somewhat neglected, as techniques for measuring it are laborious and/or require large numbers of cells. A miniaturized version of the DNA repair assay using a smaller number of cells would be very useful.

The question of whether DNA damage can be a predictive marker of cancer risk will only be answered by a prospective or retrospective trial, in which DNA damage is measured in a large number of healthy subjects who are subsequently monitored over many years for the occurrence of disease or death. The possibility of using stored blood or buffy coat samples from existing prospective studies should be explored.

There is an ongoing debate over the best method for short- and long-term storage of human blood and isolated blood cells. Many of us were surprised by the finding that small volumes of blood could 
be snap-frozen without any special precautions such as are routinely used to preserve larger volumes [144,184]. Validated standard procedures would be very useful. There is also a need for further comparative study of the kinds and levels of damage in different blood cell fractions, and the correlation (or otherwise) between them.

As described above, disparate results have been reported concerning effects on DNA damage levels of smoking, various exposures, season of sampling, age, sex etc. In an attempt to resolve these issues, a pooled analysis of data from a large number of studies (involving almost 20,000 individual subjects) is being undertaken by hCOMET. Using a database this large, it may be possible to rank the effect of potential confounders and thus distinguish important confounders from those that have had little or inconsistent effect on DNA damage levels measured with the comet assay.

\section{Final considerations}

The comet assay for DNA damage and repair is now very well established as a biomonitoring tool, in various contexts: in crosssectional studies, prospective cohort studies, case-control studies, and intervention trials. It has been applied to studies of occupational and environmental exposure, nutrition, disease risk, or simply used to investigate comparative levels of DNA damage/ repair in different groups (for instance men, women and children, or different age groups, or vegetarians and omnivores). It is perhaps surprising that it is used successfully in spite of the excessive inter-laboratory variability that has been demonstrated in various ring studies; it would certainly be reassuring if this variability could be reduced or eliminated. It is probably too much to expect that laboratories will adopt a standard procedure, but an appreciation of which experimental variables are crucially important and which do not matter would help. It should be mandatory to include reference standards, and to report in publications the critical experimental variables. The use of appropriate statistical methods in analysing comet assay data is essential, but to date this has too often been neglected. It should be clear that a wellperformed comet assay experiment (i.e. with high technical skills in the laboratory) may be wasted if little attention has been paid to epidemiological principles including proper study design and statistical analysis. Simple statistical tests such as the Student's $t$ test or the Mann-Whitney $U$ test are applicable in biomonitoring studies on binary exposures categories if there is adequate control of confounders. However, the situation is typically complex as most exposures and co-variates are continuous variables and even controlled exposure studies (e.g. intervention trials) may have subjects dropping out of the study or loss of samples. This "loss to follow-up" may lead to disproportionate distribution of confounders in exposure groups. Statistical planning to ameliorate the impact of such events should be considered as a good investment for biomonitoring studies using the comet assay.

\section{Funding}

This research did not receive any specific grant from funding agencies in the public, commercial, or not-for-profit sectors.

\section{Conflict of interest}

None.

\section{Acknowledgements}

The authors are grateful to the COST Action CA15132, 'hCOMET', for support. Amaya Azqueta thanks the Ministry of Economy,
Industry and Competitiveness ('Ramón y Cajal' programme, RYC2013-14370) of the Spanish Government for personal support. The work of Stefano Bonassi and Monica Neri was supported by grants funded by the Italian Ministry of Health [Institutional Research 2017-2018], and by AIRC (Associazione Italiana per la Ricerca sul Cancro), IG2015/17564.

\section{References}

[1] J. Angerer, U. Ewers, M. Wilhelm, Human biomonitoring: state of the art, Int. J Hyg. Environ. Health 210 (2007) 201-228.

[2] World Health Organization (WHO), Human Biomonitoring: Facts and Figures, WHO Regional Office for Europe, 2015.

[3] P. Møller, S. Loft, C. Ersson, G. Koppen, M. Dusinska, A.R. Collins, On the search for an intelligible comet assay descriptor, Front. Genet. 5 (2014) 217.

[4] A. Azqueta, D. Muruzabal, E. Boutet-Robinet, M. Milic, M. Dusinska, G. Brunborg, P. Møller, A.R. Collins, Technical recommendations to perform the alkaline standard and enzyme-modified comet assay in human biomonitoring studies, Mutat. Res. 843 (2019) 24-32.

[5] ESCODD (European Standards Committee on Oxidative DNA Damage) Comparative analysis of baseline 8-oxo-7,8-dihydroguanine in mammalian cell DNA, by different methods in different laboratories: an approach to consensus, Carcinogenesis 23 (2002) 2129-2133.

[6] ESCODD (European Standards Committee on Oxidative DNA Damage), Measurement of DNA oxidation in human cells by chromatographic and enzymic methods, Free Radic. Biol. Med. 34 (2003) 1089-1099.

[7] C.M. Gedik, A.R. Collins, ESCODD (European Standards Committee on Oxidative DNA Damage), establishing the background level of base oxidation in human lymphocyte DNA: results of an inter-laboratory validation study, FASEB J. 19 (2005) 82-84

[8] P. Møller, L. Möller, R.W. Godschalk, G.D. Jones, Assessment and reduction of comet assay variation in relation to DNA damage: studies from the European Comet Assay Validation Group, Mutagenesis 25 (2010) 109-111.

[9] L. Forchhammer, C. Johansson, S. Loft, L. Möller, R.W. Godschalk, S.A. Langie G.D. Jones, R.W. Kwok, A.R. Collins, A. Azqueta, D.H. Phillips, O. Sozeri, M. Stepnik, J. Palus, U. Vogel, H. Wallin, M.N. Routledge, C. Handforth, A. Allione, G. Matullo, J.P. Teixeira, S. Costa, P. Riso, M. Porrini, P. Møller, Variation in the measurement of DNA damage by comet assay measured by the ECVAG interlaboratory validation trial, Mutagenesis 25 (2010) 113-123.

[10] C. Johansson, P. Møller, L. Forchhammer, S. Loft, R.W. Godschalk, S.A. Langie, S. Lumeij, G.D. Jones, R.W. Kwok, A. Azqueta, D.H. Phillips, O. Sozeri, M.N. Routledge, A.J. Charlton, P. Riso, M. Porrini, A. Allione, G. Matullo, J. Palus, M. Stepnik, A.R. Collins, L. Möller, An ECVAG trial on assessment of oxidative damage to DNA measured by the comet assay, Mutagenesis 25 (2010) 125-132.

[11] L. Forchhammer, C. Ersson, S. Loft, L. Möller, R.W. Godschalk, F.J. van Schooten, G.D. Jones, J.A. Higgins, M. Cooke, V. Mistry, M. Karbaschi, A.R. Collins, A. Azqueta, D.H. Phillips, O. Sozeri, M.N. Routledge, K. Nelson-Smith, P. Riso, M. Porrini, G. Matullo, A. Allione, M. Steepnik, M. Komorowska, J.P. Teixeira, S. Costa, L.A. Corcuera, A. Lopez de Cerain, B. Laffon, V. Valdiglesias, P. Møller, Inter-laboratory variation in DNA damage using a standard comet assay protocol, Mutagenesis 27 (2012) 665-672.

[12] C. Ersson, P. Møller, L. Forchhammer, S. Loft, A. Azqueta, R.W.L. Godschalk, F.J van Schooten, G.D.D. Jones, J.A. Higgins, M.S. Cooke, V. Mistry, M. Karbaschi, D.H. Phillips, O. Sozeri, M.N. Routledge, K. Nelson-Smith, P. Riso, M. Porrini, G. Matullo, A. Allione, M. Stepnik, M. Ferlinska, J.P. Teixeira, S. Costa, L.A. Corcuera, A. Lopez de Cerain, B. Laffon, V. Valdiglesias, A.R. Collins, L. Möller An ECVAG inter-laboratory validation study of the comet assay: inter- and intra-laboratory variation of DNA strand breaks and FPG-sensitive sites in human mononuclear cells, Mutagenesis 28 (2013) 279-286.

[13] R.W. Godschalk, C. Ersson, M. Stepnik, M. Ferlinska, J. Palus, J.P. Teixeira, S. Costa, G.D. Jones, J.A. Higgins, J. Kain, L. Möller, L. Forchhammer, S. Loft, Y. Lorenzo, A.R. Collins, F.J. van Schooten, B. Laffon, V. Valdiglesias, M. Cooke, V. Mistry, M. Karbaschi, D.H. Phillips, O. Sozeri, M.N. Routledge, K. NelsonSmith, P. Riso, M. Porrini, A. Lopez de Cerain, A. Azqueta, G. Matullo, A. Allione, P. Møller, Variation of DNA damage levels in peripheral blood mononuclear cells isolated in different laboratories, Mutagenesis 29 (2014) 241-249.

[14] P. Møller, Effect of age and sex on the level of DNA strand breaks and oxidatively damaged DNA in human blood cells, Mutat. Res. 838 (2019) $16-21$.

[15] P. Møller, L.E. Knudsen, S. Loft, H. Wallin, The comet assay as a rapid test in biomonitoring occupational exposure to DNA-damaging agents and effect of confounding factors, Cancer Epidemiol. Biomarkers Prev. 9 (2000) 1005-1015.

[16] P. Møller, Assessment of reference values for DNA damage detected by the comet assay in humans blood cell DNA, Mutat. Res. 612 (2006) 84-104.

[17] V. Humphreys, R.M. Martin, B. Ratcliffe, S. Duthie, S. Wood, D. Gunnell, A.R Collins, Age-related increases in DNA repair and antioxidant protection: a comparison of the Boyd Orr Cohort of elderly subjects with a younger population sample, Age Ageing 36 (2007) 521-526.

[18] S.M. Piperakis, K. Kontogianni, G. Karanastasi, Z. Iakovidou-Kritsi, M.M Piperakis, The use of comet assay in measuring DNA damage and repair efficiency in child, adult, and old age populations, Cell Biol. Toxicol. 25 (2009) $65-71$. 
[19] M.P. Mota, F.M. Peixoto, J.F. Soares, P.A. Figueiredo, J.C. Leitao, I. Gaivao, J.A. Duarte, Influence of aerobic fitness on age-related lymphocyte DNA damage in humans: relationship with mitochondria respiratory chain and hydrogen peroxide production, Age (Dordr) 32 (2010) 337-346.

[20] J.P. Soares, M.P. Mota, J.A. Duarte, A.R. Collins, I. Gaivao, Age-related increases in human lymphocyte DNA damage: is there a role of aerobic fitness? Cell Biochem. Funct. 31 (2013) 743-748.

[21] M.M. Dobrzynska, K.A. Pachocki, K. Owczarska, DNA strand breaks in peripheral blood leucocytes of Polish blood donors, Mutagenesis 33 (2018) 69-76.

[22] H. Weng, Z. Weng, Y. Lu, K. Nakayama, K. Morimoto, Effects of cigarette smoking, XRCC1 genetic polymorphisms, and age on basal DNA damage in human blood mononuclear cells, Mutat. Res. 679 (2009) 59-64.

[23] M. Mladinic, N. Kopjar, M. Milic, A.B. Dasovic, M. Huzak, D. Zeljezic, Genomic instability in a healthy elderly population: a pilot study of possible cytogenetic markers related to ageing, Mutagenesis 25 (2010) 455-462.

[24] V.M. Mendoza-Nunez, A. Beristain-Perez, S.P. Perez-Vera, M.A. AltamiranoLozano, Age-related sex differences in glutathione peroxidase and oxidative DNA damage in a healthy Mexican population, J. Womens Health (Larchmt.) 19 (2010) 919-926.

[25] L. Giovannelli, V. Pitozzi, S. Moretti, V. Boddi, P. Dolara, Seasonal variations of DNA damage in human lymphocytes: correlation with different environmental variables, Mutat. Res. 593 (2006) 143-152.

[26] N. Kopjar, D. Zeljezic, V. Garaj-Vrhovac, Evaluation of DNA damage in white blood cells of healthy human volunteers using the alkaline comet assay and the chromosome aberration test, Acta Biochim. Pol. 53 (2006) 321-336.

[27] J. Slyskova, A. Naccarati, V. Polakova, B. Pardini, L. Vodickova, R. Stetina, J. Schmuczerova, Z. Smerhovsky, L. Lipska, P. Vodicka, DNA damage and nucleotide excision repair capacity in healthy individuals, Environ. Mol. Mutagen. 52 (2011) 511-517.

[28] M. Løhr, A. Jensen, L. Eriksen, M. Grønbæk, S. Loft, P. Møller, Age and metabolic risk factors associated with oxidatively damaged DNA in human peripheral blood mononuclear cells, Oncotarget 6 (2015) 2641-2653.

[29] N.P. Sirota, E.A. Kuznetsova, Spontaneous DNA damage in peripheral blood leukocytes from donors of different age, Bull. Exp. Biol. Med. 145 (2008) 194197.

[30] P. Hyland, O. Duggan, J. Turbitt, J. Coulter, A. Wikby, B. Johansson, A. Tompa, C. Barnett, Y. Barnett, Nonagenarians from the Swedish NONA immune study have increased plasma antioxidant capacity and similar levels of DNA damage in peripheral blood mononuclear cells compared to younger control subjects, Exp. Gerontol. 37 (2002) 465-473.

[31] J.L. Watters, J.A. Satia, L.L. Kupper, J.A. Swenberg,, J.C. Schroeder, B.R. Switzer, Associations of antioxidant nutrients and oxidative DNA damage in healthy African-American and White adults, Cancer Epidemiol. Biomarkers Prev. 16 (2007) 1428-1436.

[32] A.R. Trzeciak, J.G. Mohanty, K.D. Jacob, J. Barnes, N. Ejiogu, A. Lohani, A.B. Zonderman, J.M. Rifkind, M.K. Evans, Oxidative damage to DNA and single strand break repair capacity: relationship to other measures of oxidative stress in a population cohort, Mutat. Res. 736 (2012) 93-103.

[33] M. Geric, G. Gajski, V. Orešcanin, V. Garaj-Vrhovac, Seasonal variations as predictive factors of the comet assay parameters: a retrospective study, Mutagenesis 33 (2018) 53-60.

[34] G. Gajski, M. Geric, V. Orescanin, V. Garaj-Vrhovac, Cytogenetic status of healthy children assessed with the alkaline comet assay and the cytokinesisblock micronucleus cytome assay, Mutat. Res. 750 (2013) 55-62.

[35] P. Møller, H. Wallin, E. Holst, L.E. Knudsen, Sunlight induced DNA damage in human mononuclear cells, FASEB J. 16 (2002) 45-53.

[36] T. Hofer, H.L. Karlsson, L. Möller, DNA oxidative damage and strand breaks in young healthy individuals: a gender difference and the role of life style factors, Free Radic. Res, 40 (2006) 707-714.

[37] S.W. Cash, S.A. Beresford, T.L. Vaughan, P.J. Heagerty, L. Bernstein, E. White, M. L. Neuhouser, Recent physical activity in relation to DNA damage and repair using the comet assay, J. Phys. Act. Health 11 (2014) 770-776.

[38] F. Kassie, W. Parzefall, S. Knasmüller, Single cell gel electrophoresis assay: a new technique for human biomonitoring studies, Mutat. Res. 463 (2000) 13-31.

[39] F. Faust, F. Kassie, S. Knasmuller, R.H. Boedecker, M. Mann, V. MerschSundermann, The use of the alkaline comet assay with lymphocytes in human biomonitoring studies, Mutat. Res. 566 (2004) 209-229.

[40] H. Hoffmann, J. Hogel, G. Speit, The effect of smoking on DNA effects in the comet assay: a metaanalysis, Mutagenesis 20 (2005) 455-466.

[41] A.R. Collins, G. Koppen, V. Valdiglesias, M. Dusinska, M. Kruszewski, P. Møller, E. Rojas, A. Dhawan, I. Benzie, E. Coskun, M. Moretti, G. Speit, S. Bonassi, The comet assay as a tool for human biomonitoring studies: the ComNet Project, Mutat. Res. 759 (2014) 27-39.

[42] A. Kocyigit, S. Selek, H. Celik, M. Dikilitas, Mononuclear leukocyte DNA damage and oxidative stress: the association with smoking of hand-rolled and filter-cigarettes, Mutat. Res. 721 (2011) 136-141.

[43] T.H. Lam, C.Q. Zhu, C.Q. Jiang, Lymphocyte DNA damage in elevator manufacturing workers in Guangzhou, China, Mutat. Res. 515 (2002) 147157.

[44] M.E. Fracasso, D. Doria, P. Franceschetti, L. Perbellini, L. Romeo, DNA damage and repair capacity by comet assay in lymphocytes of white-collar active smokers and passive smokers (non- and ex-smokers) at workplace, Toxicol. Lett. 167 (2006) 131-141.

[45] R. Chandirasekar, B. Lakshman Kumar, K. Sasikala, R. Jayakumar, K. Suresh, R. Venkatesan, Raichel Jacob, E.K. Krishnapriya, H. Kavitha, G. Karthik Ganeshd,
Assessment of genotoxic and molecular mechanisms of cancer risk in smoking and smokeless tobacco users, Mutat. Res. 767 (2014) 21-27.

[46] S. Sardas, B. Cimen, S. Karsli, T. Yurdun, L. Donbak, Comparison of genotoxic effect between smokeless tobacco (Maras powder) users and cigarette smokers by the alkaline comet assay, Hum. Exp. Toxicol. 28 (2009) 214-219.

[47] C. Ladeira, L. Smajdova, The use of genotoxicity biomarkers in molecular epidemiology: applications in environmental, occupational and dietary studies, AIMS Genet. 4 (2007) 166-191.

[48] P.J. Landrigan, R. Fuller, N.J.R. Acosta, O. Adeyi, R. Arnold, N.N. Basu, A.B. Baldé, R. Bertollini, S. Bose-O'Reilly, J. Boufford, P.N. Breysse, T. Chiles, C. Mahido, A. M. Coll-Seck, M.L. Cropper, J. Fobil, V. Fuster, M. Greenstone, A. Haines, D. Hanrahan, D. Hunter, M. Khare, A. Krupnick, B. Lanphear, B. Lohani, K. Martin, K.V. Mathiasen, M.A. McTeer, C.J.L. Murray, J.D. Ndahimananjara, F. Perera, J. Potočnik, A.S. Preker, J. Ramesh, J. Rockström, C. Salinas, L.D. Samson, K. Sandilya, P.D. Sly, K.R. Smith, A. Steiner, R.B. Stewart, W.A. Suk, O.C.P. van Schayck, G.N. Yadama, K. Yumkella, M. Zhong, The Lancet Commission on pollution and health, Lancet 391 (2018) 462-512.

[49] M. Valverde, E. Rojas, Environmental and occupational biomonitoring using the comet assay, Mutat. Res. 681 (2009) 93-109.

[50] D. Cavallo, C.L. Ursini, G. Carelli, I. Iavicoli, A. Ciervo, B. Perniconi, B, Rondinone, M. Gismondi, S. Iaavicoli, Occupational exposure in airport personnel: characterisation and evaluation of genotocic and oxidative effects, Toxicology 223 (2006) 26035.

[51] B. Novotna, J. Topinka, I. Solansky, I. Chvatalova, Z. Lnenickova, R.J. Sram, Impact of air pollution and genotype variability on DNA damage in Pargaue policemen, Toxicol. Lett. 172 (2007) 37-47.

[52] T. Setayesh, A. Nersesyan, M. Mišík, F. Ferk, S. Langie, V.M. Andrade, A. Haslberger, S. Knasmüller, Impact of obesity and overweight on DNA stability: few facts and many hypotheses, Mutat. Res. 777 (2018) 64-91.

[53] G. Gandhi, G. Kaur, Assessment of DNA damage in obese individuals, Res. J. Biol. 2 (2012) 37-44.

[54] S.A. Bukhari, M. Rajoka, S.A. Nagra, Z.U. Rehman, Plasma homocysteine and DNA damage profiles in normal and obese subjects in the Pakistani population, Mol. Biol. Rep. 37 (2010) 289-295.

[55] S.I. Tsilimigaki, N. Messini-Nikolaki, M. Kanariou, S.M. Piperakis, A study on the effects of seasonal solar radiation on exposed populations, Mutagenesis 18 (2003) 139-143.

[56] L. Verschaeve, G. Koppen, U. Van Gorp, G. Schoeters, G. Jacobs, C. Zwijzen, Seasonal variations in spontaneous levels of DNA damage; implication in the risk assessment of environmental chemicals, J. Appl. Toxicol. 27 (2007) 612620.

[57] G. Koppen, G. De Prins, S. Cox, B. Nelen, V. Spruyt, M. Van De Weghe, H. Nawrot, T. Schoeters, Panel study on indoor exposure to polyaromatic hydrocarbons in relation to DNA damage biomarkers, Front. Genet. (2015) Conference Abstract: ICAW 2015 - 11th International Comet Assay Workshop.

[58] G. Koppen, G. Verheyen, A. Maes, U. Van Gorp, G. Schoeters, E. Den Hond, J. Staessen, T. Nawrot, H.A. Roels, R. Vlietinck, L. Verschaeve, A battery of DNA effect biomarkers to evaluate environmental exposure of Flemish adolescents, J. Appl. Toxicol. 27 (2007) 238-246.

[59] R.J. Srám, I. Benes, B. Binková, J. Dejmek, D. Horstman, F. Kotĕsovec, D. Otto, S. D. Perreault, J. Rubes, S.G. Selevan, I. Skalík, R.K. Stevens, J. Lewtas, Teplice program-the impact of air pollution on human health, Environ. Health Perspect. 104 (1996) 699-714.

[60] F.P. Perera, K. Hemminki, E. Gryzbowska, G. Motykiewicz, J. Michalska, R.M. Santella, T.L. Young, C. Dickey, P. Brandt-Rauf, I. De Vivo, Molecular and genetic damage in humans from environmental pollution in Poland, Nature. 360 (1992) 256-258.

[61] S.A. Geras'kin, J.K. Kimb, A.A. Oudalova, Bio-monitoring the genotoxicity of populations of Scots pine in the vicinity of a radioactive waste storage facility, Mutat. Res. 583 (2005) 55-66.

[62] J. Choi, T.A. Morck, A. Joas, L. Knudsen, Major national human biomonitoring programs in chemical exposure assessment, Environ. Sci. 2 (2015) 782-802.

[63] J. da Silva, DNA damage induced by occupational and environmental exposure to miscellaneous chemicals, Mutat. Res. 770 (2016) 170-182.

[64] P. Møller, S. Loft, Oxidative damage to DNA and lipids as biomarkers of exposure to air pollution, Environ. Health Perspect. 118 (2010) 1126-1136.

[65] P.H. Avogbe, L. Ayi-Fanou, H. Autrup, S. Loft, B. Fayomi, A. Sanni, P. Vinzents, P. Møller, Untrafine particulate matter and high-level benzene urban air pollution in relation to oxidative DNA damage, Carcinogenesis 26 (2005) 613-620.

[66] P.S. Vinzents, P. Møller, M. Sørensen, L.E. Knudsen, O. Hertel, F.P. Jensen, B. Schibye, S. Loft, Personal exposure to ultrafine particles and oxidative DNA damage, Environ. Health Perspect. 113 (2005) 1485-1490.

[67] E.V. Bräuner, L. Forchhammer, P. Møller, J. Simonsen, M. Glasius, P. Wåhlin, O. Raaschou-Nielsen, S. Loft, Exposure to ultrafine particles from ambient air and oxidative stress-induced DNA damage, Environ. Health Perspect. 115 (2007) 1177-1182.

[68] J.G. Hemmingsen, K. Jantzen, P. Møller, S. Loft, No oxidative stress or DNA damage in peripheral blood mononuclear cells after exposure to particles from urban street air in overweight elderly, Mutagenesis 30 (2015) 635-642.

[69] J.G. Hemmingsen, P. Møller, K. Jantzen, B.A. Jönsson, M. Albin, A. Wierzbicka, A. Gudmundsson, S. Loft, J. Rissler, Controlled exposure to diesel exhaust and traffic noise-effects on oxidative stress and activation in mononuclear blood cells, Mutat. Res. 775 (2015) 66-71.

[70] P.H. Danielsen, E.V. Bräuner, L. Barregard, G. Sällsten, M. Wallin, R. Olinski, R. Rozalski, P. Møller, S. Loft, Oxidatively damaged DNA and its repair after 
experimental exposure to wood smoke in healthy humans, Mutat. Res. 642 (2008) 37-42.

[71] L. Forchhammer, P. Møller, I.S. Riddervold, J. Bønløkke, A. Massling, T. Sigsgaard, S. Loft, Controlled human wood smoke exposure: oxidative stress, inflammation and microvascular function, Part. Fibre Toxicol. 9 (2012) 7.

[72] A. Jensen, D.G. Karottki, J.M. Christensen, J.H. Bønløkke, T. Sigsgaard, M. Glasius, S. Loft, P. Møller, Biomarkers of oxidative stress and inflammation after wood smoke exposure in a reconstructed Viking Age house, Environ. Mol. Mutagen. 55 (2014) 652-661.

[73] A. Abreu, C. Costa, S. Pinho, E. Silva, S. Morais, M. do Carmo Pereira, A. Fernandes, V. Moraes de Andrade, J.P. Teixeira, S. Costa, Wood smoke exposure of Portuguese wildland firefighters: DNA and oxidative damage evaluation, J. Toxicol. Environ. Health A 80 (2017) 596-604.

[74] K. Jantzen, A. Jensen, A. Kermanizadeh, G. Elholm, T. Sigsgaard, P. Møller, M. Roursgaard, S. Loft, Inhalation of house dust and ozone alters systemic levels of endothelial progenitor cells, oxidative stress, and inflammation in elderly subjects, Toxicol. Sci. 163 (2018) 353-363.

[75] A. Marcon, M.E. Fracasso, P. Marchetti, D. Doria, P. Girardi, L. Guarda, G. Pesce, V. Pironi, P. Ricci, R. de Marco, Outdoor formaldehyde and $\mathrm{NO}_{2}$ exposures and markers of genotoxicity in children living near chipboard industries, Environ. Health Perspect. 122 (2014) 639-645.

[76] R.T. Gamboa, A.R. Gamboa, A.H. Bravo, W.P. Ostrosky, Genotoxicity in child populations exposed to polycyclic aromatic hydrocarbons (PAHs) in the air from Tabasco, Mexico, Int. J. Environ. Res. Public Health 5 (2008) 349-355.

[77] S. De Coster, G. Koppen, M. Bracke, C. Schroijen, E. Den Hond, V. Nelen, E. Van de Mieroop, L. Bruckers, M. Bilau, W. Baeyens, G. Schoeters, N. van Larebeke, Pollutant effects on genotoxic parameters and tumor-associated protein levels in adults: a cross sectional study, Environ. Health 7 (2008) 26.

[78] N. Ataseven, D. Yüzbaşıŏlu, A.Ç. Keskin, F. Ünal, Genotoxicity of monosodium glutamate, Food Chem. Toxicol. 91 (2016) 8-18.

[79] D. Anderson, T.W. Yu, R.J. Hambly, M. Mendy, C.P. Wild, Aflatoxin exposure and DNA damage in the comet assay in individuals from the Gambia, West Africa, Teratog. Carcinog. Mutagen. 19 (1999) 147-155.

[80] A.M. Joosen, G.G. Kuhnle, S.M. Aspinall, T.M. Barrow, E. Lecommandeur, A. Azqueta, A.R. Collins, S.A. Bingham, Effect of processed and red meat on endogenous nitrosation and DNA damage, Carcinogenesis 30 (2009) 1402-1407.

[81] M. Dusinska, A.R. Collins, The comet assay in human biomonitoring: geneenvironment interactions, Mutagenesis 23 (2008) 191-205.

[82] P. Møller, A. Jensen, M. Løhr, L. Eriksen, M. Grønbæk, S. Loft, Fish and salad consumption are inversely associated with levels of oxidatively damaged DNA in a Danish adult cohort, Mutat. Res. 843 (2019) 66-72.

[83] S.J. Duthie, A. Ma, M.A. Ross, A.R. Collins, Antioxidant supplementation decreases oxidative DNA damage in human lymphocytes, Cancer Res. 56 (1996) 1291-1295.

[84] T. Bakuradze, R. Lang, T. Hofmann, G. Eisenbrand, D. Schipp, J. Galan, E. Richling, Consumption of a dark roast coffee decreases the level of spontaneous DNA strand breaks: a randomized controlled trial, Eur. J. Nutr. 54 (2015) 149-156.

[85] E. Müllner, H. Brath, S. Pleifer, C. Schiermayr, A. Baierl, M. Wallner, T. Fastian, Y. Millner, K. Paller, T. Henriksen, H.E. Poulsen, E. Forster, K.H. Wagner, Vegetables and PUFA-rich plant oil reduce DNA strand breaks in individuals with type 2 diabetes, Mol. Nutr. Food Res. 57 (2013) 328-338.

[86] Y.J. Kim, Y.H. Ahn, Y. Lim, J.Y. Kim, J. Kim, O. Kwon, Daily nutritional dose supplementation with antioxidant nutrients and phytochemicals improves DNA and LDL stability: a double-blind, randomized, and placebo-controlled trial, Nutrients 5 (2013) 5218-5232.

[87] B. Moser, T. Szekeres, C. Bieglmayer, K.H. Wagner, M. Mišík, M. Kundi, O. Zakerska, A. Nersesyan, N. Kager, J. Zahrl, C. Hoelzl, V. Ehrlich, S. Knasmueller, Impact of spinach consumption on DNA stability in peripheral lymphocytes and on biochemical blood parameters: results of a human intervention trial, Eur. J. Nutr. 50 (2011) 587-594.

[88] P. Riso, A. Pinder, A. Santangelo, M. Porrini, Does tomato consumption effectively increase the resistance of lymphocyte DNA to oxidative damage? Am. J. Clin. Nutr. 69 (1999) 712-718.

[89] M. Porrini, P. Riso, Lymphocyte lycopene concentration and DNA protection from oxidative damage is increased in women after a short period of tomato consumption, J. Nutr. 130 (2000) 189-192.

[90] Y.T. Szeto, Y.S. Sin, S.C. Pak, W. Kalle, American ginseng tea protects cellular DNA within $2 \mathrm{~h}$ from consumption: results of a pilot study in healthy human volunteers, Int. J. Food Sci. Nutr. 66 (2015) 815-818.

[91] C. Del Bo', P. Riso, J. Campolo, P. Møller, S. Loft, D. Klimis-Zacas, A. Brambilla, A. Rizzolo, M. Porrini, A single portion of blueberry (Vaccinium corymbosum L) improves protection against DNA damage but not vascular function in healthy male volunteers, Nutr. Res. 33 (2013) 220-227.

[92] S. Guarnieri, P. Riso, M. Porrini, Orange juice vs vitamin C: effect on hydrogen peroxide-induced DNA damage in mononuclear blood cells, Br. J. Nutr. 97 (2007) 639-643.

[93] B.H. Collins, A. Horská, P.M. Hotten, C. Riddoch, A.R. Collins, Kiwifruit protects against oxidative DNA damage in human cells and in vitro, Nutr. Cancer 39 (2001) 148-153.

[94] T. Bakuradze, R. Lang, T. Hofmann, D. Schipp, J. Galan, G. Eisenbrand, E. Richling, Coffee consumption rapidly reduces background DNA strand breaks in healthy humans: results of a short-term repeated uptake intervention study, Mol. Nutr. Food Res. 60 (2016) 682-686.

[95] K. Briviba, B.A. Stracke, C.E. Rüfer, B. Watzl, F.P. Weibel, A. Bub, Effect of consumption of organically and conventionally produced apples on antioxidant activity and DNA damage in humans, J. Agric. Food Chem. 55 (2007) 7716-7721.

[96] C. Del Bo', M. Porrini, J. Campolo, M. Parolini, C. Lanti, D. Klimis-Zacas, P. Riso, A single blueberry (Vaccinium corymbosum) portion does not affect markers of antioxidant defence and oxidative stress in healthy volunteers following cigarette smoking, Mutagenesis 31 (2016) 215-224.

[97] S.J. Duthie, Folate and cancer: how DNA damage and DNA repair impact on colon carcinogenesis, J. Inherit. Metab. Dis. 34 (2011) 101-109.

[98] S.J. Duthie, A. Hawdon, DNA instability (strand breakage, uracil misincorporation and defective repair) is increased by folic acid depletion in human lymphocytes, FASEB J. 12 (1998) 1491-1497.

[99] G.P. Basten, S.J. Duthie, L. Pirie, M.H. Hill, H.J. Powers, Sensitivity of markers of DNA stability and repair activity to folate supplementation in healthy volunteers, Br. J. Cancer 94 (2006) 1942-1947.

[100] B.L. Pool-Zobel, A. Bub, H. Müller, I. Wollowski, G. Rechkemmer, Consumption of vegetables reduces genetic damage in humans: first results of a human intervention trial with carotenoid-rich foods, Carcinogenesis 18 (1997) 1847 1850.

[101] K. Briviba, S.E. Kulling, J. Möseneder, B. Watzl, G. Rechkemmer, A. Bub, Effects of supplementing a low-carotenoid diet with a tomato extract for 2 weeks on endogenous levels of DNA single strand breaks and immune functions in healthy non-smokers and smokers, Carcinogenesis 25 (2004) 2373-2378.

[102] A.R. Collins, V. Harrington, J. Drew, R. Melvin, Nutritional modulation of DNA repair in a human intervention study, Carcinogenesis (2003) 511-515.

[103] A. Brevik, I. Gaivão, T. Medin, A. Jørgenesen, A. Piasek, J. Elilasson, A. Karlsen, R. Blomhoff, T. Veggan, A.K. Duttaroy, A.R. Collins, Supplementation of a western diet with golden kiwifruits (Actinidia chinensis var.'Hort 16A':) effects on biomarkers of oxidation damage and antioxidant protection, Nutr. J. 10 (2011) 54.

[104] P. Riso, D. Martini, F. Visioli, A. Martinetti, M. Porrini, Effect of broccoli intake on markers related to oxidative stress and cancer risk in healthy smokers and nonsmokers, Nutr. Cancer 61 (2009) 232-237.

[105] P. Riso, D. Martini, P. Møller, S. Loft, G. Bonacina, M. Moro, M. Porrini, DNA damage and repair activity after broccoli intake in young healthy smokers, Mutagenesis 25 (2010) 595-602.

[106] P. Riso, D. Klimis-Zacas, C. Del Bo', D. Martini, J. Campolo, S. Vendrame, P. Møller, S. Loft, R. De Maria, M. Porrini, Effect of a wild blueberry (Vaccinium angustifolium) drink intervention on markers of oxidative stress,

inflammation and endothelial function in humans with cardiovascular risk factors, Eur. J. Nutr. 52 (2013) 949-961.

[107] F. Guaraldi, V. Deon, C. Del Bo', S. Vendrame, M. Porrini, P. Riso, O. Guardamagna, Effect of short term hazelnut consumption on DNA damage and oxidized-LDL in children and adolescents with primary hyperlipidemia: a randomised controlled trial, J. Nutr. Biochem. 57 (2018) 206-211.

[108] J.L. Chang, G. Chen, C.M. Ulrich, J. Bigler, I.B. King, Y. Schwarz, S. Li, L. Li, J.D. Potter, J.W. Lampe, DNA damage and repair: fruit and vegetable effects in a feeding trial, Nutr. Cancer 62 (2010) 329-335.

[109] S.J. Duthie, A.M. Jenkinson, A. Crozier, W. Mullen, L. Pirie, J. Kyle, L.S. Yap, P. Christen, G.G. Duthie, The effects of cranberry juice consumption on antioxidant status and biomarkers relating to heart disease and cancer in healthy human volunteers, Eur. J. Nutr. 45 (2006) 113-122.

[110] K. Briviba, A. Bub, J. Möseneder, T. Schwerdtle, A. Hartwig, S. Kulling, B. Watzl No differences in DNA damage and antioxidant capacity between intervention groups of healthy, nonsmoking men receiving 2,5 , or 8 servings/ day of vegetables and fruit, Nutr. Cancer 60 (2008) 164-170.

[111] P. Møller, H. Wallin, L.E. Knudsen, Oxidative stress associated with exercise, psychological stress and life style factors, Chem. Biol. Interact. 102 (1996) 1736.

[112] A. Hartmann, U. Plapperet, K. Raddatz, M. Grünert-Fuchs, G. Speit, Does physical activity induce DNA damage? Mutagenesis 9 (1994) 269-272.

[113] A. Hartmann, A.M. Niess, M. Grünert-Fuchs, B. Poch, G. Speit, Vitamin prevents exercise-induced DNA damage, Mutat. Res. 346 (1995) 195-202.

[114] A.M. Niess, A. Hartmann, M. Grünert-Fuchs, B. Poch, G. Speit, DNA-damage after exhaustive treadmill running in trained and untrained men, Int. J. Sports Med. 17 (1996) 397-403.

[115] A. Hartmann, S. Pfuhler, C. Dennog, D. Germdnik, A. Pilger, G. Speit, Exerciseinduced DNA effects in human leukocytes are not accompanied by increased formation of 8-hydroxy-2-deoxyguanosine or induction of micronuclei, Free Radic. Biol. Med. 24 (1998) 245-251.

[116] K.H. Wagner, S. Reichhold, C. Hölzl, S. Knasmüller, L. Nics, M. Meisel, O Neubauer, Well-trained, healthy triathletes experience no adverse health risks regarding oxidative stress and DNA damage by participating in an ultraendurance event, Toxicology 278 (2010) 211-216.

[117] P. Møller, S. Loft, C. Lundby, N.V. Olsen, Acute hypoxia and hypoxic exercise induce DNA strand breaks and oxidative DNA damage in humans, FASEB J. 15 (2001) 1181-1186.

[118] M. Mergener, M.R. Martins, M.V. Antunes, C. Calice da Silva, C. Lazzaretti, T.O. Fontanive, E.S. Suyenaga, P.G. Ardenghi, S.W. Maluf, G.D. Gamaro, Oxidative stress and DNA damage in older adults that do exercises regularly, Clin. Biochem. 42 (2009) 1648-1653.

[119] M. Sopic, N. Bogavac-Stanojevic, I. Baralic, J. Kotur-Stevuljevic, B. Dordevic, A Stefanovic, Z. Jelic-Ivanovic, Effects of short- and long-term physical activity on DNA stability and oxidative stress status in young soccer players, J. Sports Med. Phys. Fitness 54 (2014) 354-361.

[120] F. Esteves, E. Teixeira, T. Amorim, C. Costa, C. Pereira, S. Fraga, V. Moraes De Andrade, J.P. Teixeira, S. Costa, Assessment of DNA damage in a group of 
professional dancers during a 10-month dancing season, J. Toxicol. Environ. Health A 80 (2017) 797-804.

[121] M. Atli, M. Aslan, M.E. Kucukoglu, H.B. Temur, A. Taskın, H. Celik, Peripheral lymphocyte dna damage and oxidative status in football players after a threeday football tournament, Intern. Med. 52 (2013) 213-217.

[122] J.P. Soares, A.M. Silva, M.M. Oliveira, F. Peixoto, I. Gaivão, M.P. Mota, Effects of combined physical exercise training on DNA damage and repair capacity: role of oxidative stress changes, Age (Dordr) 37 (2015) 9799.

[123] E. Kadioglu, N.A. Kocabas, G.C. Demircigil, E. Coskun, E. Ozcagli, E. Durmaz, B. Karahalil, S. Burgaz, S. Sardas, Assessment of individual susceptibility to baseline DNA and cytogenetic damage in a healthy Turkish population: evaluation with lifestyle factors, Genet. Test. Mol. Biomarkers 16 (2012) 1157-1164.

[124] J. Petrovi, D. Stani, G. Dmitrašinovi, B. Pleaš-Solarovi, S. Ignjatovi, B. Batini, D. Popovi, V. Peši, Magnesium supplementation diminishes peripheral blood lymphocyte DNA oxidative damage in athletes and sedentary young man, Oxid. Med. Cell. Longev. 2016 (2016)2019643.

[125] Y. Barranco-Ruiz, J. Aragón-Vela, C. Casals, A. Martínez-Amat, E. VillaGonzález, J.R. Huertas, Lifelong amateur endurance practice attenuates oxidative stress and prevents muscle wasting in senior adults, J. Sports Med. Phys. Fitness 57 (2017) 670-677.

[126] S. Balbo, P.J. Brooks, Implications of acetaldehyde-derived DNA adducts for understanding alcohol-related carcinogenesis, Adv. Exp. Med. Biol. 815 (2015) 71-88.

[127] P.J. Brooks, K. Schuebel, Timeless insights into prevention of acetaldehyde genotoxicity? Cell Cycle 16 (2017) 308-309.

[128] R. Retana-Ugalde, M. Altamirano-lozano, V.M. Mendoza-Núñez, Is there a similarity between dna damage in adults with chronic alcoholism and community-dwelling healthy older adults? Alcohol Alcohol. 42 (2007) 6469.

[129] J.S. Aguiar Ramos, A. Arruda Alves, M. Paiva Lopes, T.M. Alves Pedroso, L. Prado Felício, W. Fernandes Carvalho, F. Craveiro Franco, C.O. Araújo Melo, M. Wendhell Gonçalves, T. Nascimento Soares, A. Divino da Cruz, D. de Melo e Silva, DNA damage in peripheral blood lymphocytes and association with polymorphisms in the promoter region of the CYP2E1 gene in alcoholics from Central Brazil, Alcohol 57 (2016) 35-39.

[130] H. Weng, Z. Weng, Y. Lu, K. Nakayama, K. Morimoto, Effects ofalcoholdrinkingbehaviourand ADH1B and ALDH2 polymorphisms on basal DNA damage in human mononuclear cells as determined by the comet assay, Mutat. Res. 701 (2010) 132-136.

[131] B.L. Pool-Zobel, I. Dornacher, R. Lambertz, M. Knoll, H.K. Seitz, Genetic damage and repair in human rectal cells for biomonitoring: sex differences, effects of alcohol exposure, and susceptibilities in comparison to periphera blood lymphocytes, Mutat. Res. 551 (2004) 127-134.

[132] M. Milić, R. Rozgaj, V. Kašuba, V. Oreščanin, M. Balija, I. Jukić, Correlation between folate and vitamin B12 and markers of DNA stability in healthy men: preliminary results, Acta Biochim. Pol. 57 (2010) 339-345.

[133] C.Q. Zhu, T.H. Lam, C.Q. Jiang, B.X. Wei, Q.R. Xu, Y.H. Chen, Increased lymphocyte DNA strand breaks in rubber workers, Mutat. Res. 470 (2000) 201-209.

[134] F. Rombaldi, C. Cassini, M. Salvador, J. Saffi, B. Erdtmann, Occupational risk assessment of genotoxicity and oxidative stress in workers handling antineoplastic drugs during a working week, Mutagenesis 24 (2009) 143-148.

[135] M.E. Fracasso, L. Perbellini, S. Solda, G. Salamini, P. Franceschetti, Lead induced DNA strand breaks in lymphocytes of exposed workers: role of reactive oxygen species and protein kinase C, Mutat. Res. 515 (2002) 159-169.

[136] M.F. Simoniello, E.C. Kleinsorge, J.A. Scagnetti, R.A. Grigolato, G.L. Poletta, M. A. Carballo, DNA damage in workers occupationally exposed to pesticide mixtures, J. Appl. Toxicol. 28 (2008) 957-965.

[137] G. León-Mejía, L. Espitia-Pérez, L.S. Hoyos-Giraldo, J. Da Silva, A. Hartmann, J. A.P. Henriques, M. Quintana, Assessment of DNA damage in coal open-cast mining workers using the cytokinesis-blocked micronucleus test and the comet assay, Sci. Total Environ. 409 (2011) 686-691.

[138] A.M. Moro, N. Brucker, M. Charão, R. Bulcão, F. Freitas, M. Baierle, S Nascimento, J. Valentini, C. Cassini, M. Salvador, R. Linden, F. Thiesen, A. Buffon, R. Moresco, S.C. Garcia, Evaluation of genotoxicity and oxidative damage in painters exposed to low levels of toluene, Mutat. Res. 746 (2012) $42-48$.

[139] K. Ambreen, F.H. Khan, S. Bhadauria, S. Kumar, Genotoxicity and oxidative stress in chromium-exposed tannery workers in North India, Toxicol. Ind. Health 30 (2014) 405-414.

[140] Y. Carbajal-López, S. Gómez-Arroyo, R. Villalobos-Pietrini, M.E. CalderónSegura, A. Martínez-Arroyo, Biomonitoring of agricultural workers exposed to pesticide mixtures in Guerrero state, Mexico, with comet assay and micronucleus test, Environ. Sci. Pollut. Res. 23 (2016) 2513-2520.

[141] F. Biasi, M. Deiana, T. Guina, P. Gamba, G. Leonarduzzi, G. Poli, G, Wine consumption and intestinal redox homeostasis, Redox Biol. 2 (2014) 795802.

[142] G. Gajski, M. Gerić, M.V. Lovrenčić, S. Božičević, I. Rubelj, L. Nanić, N.Š Vidaček, L. Bendix, M. Peraica, D. Rašić, A.-M. Domijan, V. Gluščić, J. Jurasović, T. Orct, S.C. Avdagić, G. Jurak, J. Bošnir, V. Garaj-Vrhovac, Analysis of healthrelated biomarkers between vegetarians and non-vegetarians: a multibiomarker approach, J. Funct. Foods 48 (2018) 643-653.

[143] A. Giacosa, R. Barale, L. Bavaresco, M.A. Faliva, V. Gerbi, C. La Vecchia, E. Negri, A. Opizzi, S. Perna, M. Pezzotti, M. Rondanelli, Mediterranean way of drinking and longevity, Crit. Rev. Food Sci. Nutr. 56 (2016) 635-640.
[144] K. Al-Salmani, H.H. Abbas, S. Schulpen, M. Karbaschi, I. Abdalla, K.J. Bowman, K.K. So, M.D. Evans, G.D. Jones, R.W. Godschalk, M.S. Cooke, Simplified method for the collection, storage, and comet assay analysis of DNA damage in whole blood, Free Radic. Biol. Med. 51 (2011) 719-725.

[145] N.Y.L. Lam, T.H. Rainer, R.W.K. Chiu, Y.M.D. Lo, EDTA is a better anticoagulant than heparin or citrate for delayed blood processing for plasma DNA analysis, Clin. Chem. 50 (2004) 256-257.

[146] S.A. Salama, M. Serrana, W.W. Au, Biomonitoring using accessible human cells for exposure and health risk assessment, Mutat. Res. 436 (1999) 99-112.

[147] L. Giovannelli, V. Pitozzi, S. Riolo, P. Dolara, Measurement of DNA breaks and oxidative damage in polymorphonuclear and mononuclear white blood cells: a novel approach using the comet assay, Mutat. Res. 538 (2003) 71-80.

[148] J. Bausinger, G. Speit, The impact of lymphocyte isolation on induced DNA damage in human blood samples measured by the comet assay, Mutagenesis 31 (2016) 567-572.

[149] Z. Zhao, X. Xing, X. Ou, X. Liu, R. Zhou, H. Zhang, L. Yang, Z. Zhuang, X. Su, Y. Lu, J. Jiang, Y. Yang, D. Cui, Y. He, DNA damage levels in electronics workers in Southern China: a micro-whole blood comet assay, Mutat. Res. 803-805 (2017) 17-21.

[150] M.M. Dobrzyńska, K.A. Pachocki, A. Gajowik, J. Radzikowska, A. Sackiewicz, The effect occupational exposure to ionizing radiation on the DNA damage in peripheral blood leukocytes of nuclear medicine personnel, J. Occup. Health 56 (2014) 379-386.

[151] T.S. Kumaravel, A.N. Jha, Reliable Comet assay measurements for detecting DNA damage induced by ionising radiation and chemicals, Mutat. Res. 605 (2006) 7-16.

[152] C. Ladeira, G. Koppen, F. Scavone, L. Giovannelli, The comet assay for human biomonitoring: effect of cryopreservation on DNA damage in different blood cell preparations, Mutat. Res. 843 (2019) 11-17.

[153] S.K. Bøhn, V. Vebraitea, S. Shaposhnikov, A.R. Collins, Isolation of leukocytes from frozen buffy coat for comet assay analysis of DNA damage, Mutat. Res. 843 (2019) 18-23.

[154] E. Ceretti, C. Zani, D. Feretti, S. Vannini, M. Verani, A. De Donno, S. Bonetta, S. Montalbano, A. Biggeri, U. Gelatti, Primary DNA damage in salivary leukocytes of children exposed to air pollutants, MAPEC_LIFE project: Marco Verani. Eur. J. Public Health 27 (2017) 312.

[155] E. Ceretti, G.C. Viola, I. Zerbini, C. Zani, F. Donato, U. Gelatti, R.M. Limina, D. Feretti, Comet assay in salivary leukocytes: evaluation of early effects of air pollution exposure in pre-school children, Front. Genet. Conference Abstract: ICAW, 11th International Comet Assay Workshop, 2015.

[156] S. Vannini, S. Levorato, E. Ceretti, M. Villarini, S. Bonetta, C. Fatigoni, A. Carducci, M. Moretti, A. De Donno, T. Salvatori, A. Perotti, S. Bonizzoni, A. Bonetti, U. Gelatti, Primary and oxidative DNA damage in salivary leukocytes as a tool for the evaluation of air pollution early biological effects in children: current status of the MAPEC (monitoring air pollution effects on children for supporting public health policy) study, Front. Genet. (2015) Conference Abstract: ICAW 2015 - 11th International Comet Assay Workshop.

[157] E. Rojas, Y. Lorenzo, K. Haug, B. Nicolaissen, M. Valverde, Epithelial cells as alternative human biomatrices for comet assay, Front. Genet. 5 (2014) 386.

[158] Y.T. Szeto, I.F. Benzie, A.R. Collins, S.W. Choi, C.Y. Cheng, C.M. Yow, M.M. Tse, A buccal cell model comet assay: development and evaluation for human biomonitoring and nutritional studies, Mutat. Res. 578 (2005) 371-381.

[159] D. Cavallo, C.L. Ursini, B. Rondinone, et al., Evaluation of a suitable DNA damage biomarker for human biomonitoring of exposed workers, Environ. Mol. Mutagen. 50 (9) (2009) 781-790.

[160] P. Roy, A. Mukherjee, S. Giri, Evaluation of genetic damage in tobacco and arsenic exposed population of Southern Assam, India using buccal cytome assay and comet assay, Ecotoxicol. Environ. Saf. 124 (2016) 169-176.

[161] A. Zedginidze, E. Namchevadze, G. Ormocadze, A. Kapanadze, T. Nikuradze, D. Lomidze, Biodosimetry of persons chronically exposed to low and therapeutic doses of ionizing radiation, Genome Integr. 30 (2016) 7-12.

[162] S. Pacini, L. Giovannelli, M. Gulisano, B. Peruzzi, G. Polli, V. Boddi, M. Ruggiero, C. Bozzo, F. Stomeo, G. Fenu, S. Pezzatini, V. Pitozzi, P. Dolara, Association between atmospheric ozone levels and damage to human nasal mucosa in Florence, Italy, Environ. Mol. Mutagen. 42 (2003) 127-135.

[163] T.I. Fortoul, M. Valverde, M.C. López, M.R. Avila-Costa, M.C. Avila-Casado, P. Mussali-Galante, A. Gonzalez-Villalva, E. Rojas, P. Ostrosky-Shejet, Genotoxic differences by sex in nasal epithelium and blood leukocytes in subjects residing in a highly polluted area, Environ. Res. 94 (2004) 243-248.

[164] T.I. Fortoul, M. Valverde, C. López Mdel, P. Bizarro, I. López, I. Sánchez, L. ColínBarenque, M.R. Avila-Costa, E. Rojas, P. Ostrosky-Shejet, Single-cell gel electrophoresis assay of nasal epithelium and leukocytes from asthmatic and nonasthmatic subjects in Mexico city, Arch. Environ. Health 58 (2003) 348352.

[165] E. Rojas, M. Valverde, M.C. Lopez, I. Naufal, I. Sanchez, P. Bizarro, I. Lopez, T.I. Fortoul, P. Ostrosky-Wegman, Evaluation of DNA damage in exfoliated tear duct epithelial cells from individuals exposed to air pollution assessed by single cell gel electrophoresis assay, Mutat. Res. 468 (2000) 11-17.

[166] A. Azqueta, E. Rundén-Pran, E. Elje, B. Nicolaissen, K.H. Berg, I. Smeringaiova, K. Jirsova, A.R. Collins, The comet assay applied to cells of the eye, Mutagenesis 33 (2018) 21-24.

[167] D. Cavallo, V. Casadio, S. Bravaccini, S. Iavicoli, E. Pira, C. Romano, A.M. Fresegna, R. Maiello, A. Ciervo, G. Buresti, W. Zoli, D. Calistri, Assessment of DNA damage and telomerase activity in exfoliated urinary cells as sensitive and noninvasive biomarkers for early diagnosis of bladder cancer in exworkers of a rubber tyres industry, Biomed Res. Int. 2014 (2014) 370907. 
[168] OECD, OECD Guidelines for the Testing of Chemicals. In Vivo Mammalian Alkaline Comet Assay (TG 489), (2016) . https://www.oecd.org/env/test-no489-in-vivo-mammalian-alkaline-comet-assay-9789264264885-en.htm).

[169] C. Lundby, H. Pilegaard, G. van Hall, M. Sander, J. Calbet, S. Loft, P. Møller, Oxidative DNA damage and repair in skeletal muscle of humans exposed to high-altitude hypoxia, Toxicology 192 (2003) 229-236.

[170] A. Dhawan, D. Anderson, The Comet Assay in Toxicology, RSC Publishing, United Kingdom, 2009.

[171] C. Betti, T. Davini, L. Gianessi, N. Loprieno, R. Barale, Comparative studies by Comet test and SCE analysis in human lymphocytes from 200 healthy subjects, Mutat. Res. 343 (1995) 201-207.

[172] G. Koppen, S. De Prins, A. Jacobs, V. Nelen, G. Schoeters, S.A.S. Langie, The comet assay in human biomonitoring: cryopreservation of whole blood and comparison with isolated mononuclear cells, Mutagenesis 33 (2018) 41-47.

[173] D. Anderson, T.W. TW, M.M. Dobrzynska, G. Ribas, R. Marcos, Effects in the Comet assay of storage conditions on human blood, Teratog. Carcinog. Mutagen. 17 (1997) 115-125.

[174] A.R. Collins, The comet assay for DNA damage and repair: principles, applications, and limitations, Mol. Biotechnol. 26 (2004) 249-261.

[175] C.H. Chuang, M.L. Hu, Use of whole blood directly for single-cell gel electrophoresis (comet) assay in vivo and white blood cells for in vitro assay, Mutat. Res. 564 (2004) 75-82.

[176] S. Narayanan, M.R. O’Donovan, S.J. Duthie, Lysis of whole blood in vitro causes DNA strand breaks in human lymphocytes, Mutagenesis 16 (2001) 455-459.

[177] I. Hininger, A. Chollat-Namy, S. Sauvaigo, M. Osman, H. Faure, J. Cadet, A. Favier, A.M. Roussel, Assessment of DNA damage by comet assay on frozen total blood: method and evaluation in smokers and non-smokers, Mutat. Res. 558 (2004) 75-80.

[178] M.L. Disis, C. dela Rosa, V. Goodell, L.Y. Kuan, J.C. Chang, K. Kuus-Reichel, T.M. Clay, H. Kim Lyerly, S. Bhatia, S.A. Ghanekar, V.C. Maino, H.T. Maecker, Maximizing the retention of antigen specific lymphocyte function after cryopreservation, J. Immunol. Methods 308 (2006) 13-18.

[179] M. Zhang, H. Oldenhof, H. Sieme, W.F. Wolkers, Combining endocytic and freezing-induced trehalose uptake for cryopreservation of mammalian cells, Biotechnol. Prog. 33 (2017) 229-235.

[180] P. Jackson, L.M. Pedersen, Z.O. Kyjovska, N.R. Jacobsen, A.T. Saber, K.S. Hougaard, U. Vogel, H. Wallin, Validation of freezing tissues and cells for analysis of DNA strand break levels by comet assay, Mutagenesis 28 (2013) 699-707.

[181] X. Pu, Z. Wang, J.E. Klaunig, Cryopreservation of human blood for alkaline and Fpg-modified comet assay, Toxicol. Mech. Methods 26 (2016) 196-201.

[182] M.S. Aydin, G.E. Senturk, F. Ercan, Cryopreservation increases DNA fragmentation in spermatozoa of smokers, Acta Histochem. 115 (2013) 394-400.

[183] J.F. Muniz, L.A. McCauley, V. Pak, M.R. Lasarev, G.E. Kisby, Effects of sample collection and storage conditions on DNA damage in buccal cells from agricultural workers, Mutat. Res. 720 (2011) 8-13.

[184] M.B. Akor-Dewu, N. El Yamani, O. Bilyk, L. Holtung, T.E. Tjelle, R. Blomhoff, A. R. Collins, Leucocytes isolated from simply frozen whole blood can be used in human biomonitoring for DNA damage measurement with the comet assay, Cell Biochem. Funct. 32 (2014) 299-302.

[185] S.J. Duthie, L. Pirie, A.M. Jenkinson, S. Narayanan, Cryopreserved versus freshly isolated lymphocytes in human biomonitoring: endogenous and induced DNA damage, antioxidant status and repair capability, Mutagenesis 17 (2002) 211-214.

[186] C. Del Bo', D. Fracassetti, C. Lanti, M. Porrini, P. Riso, Comparison of DNA damage by the comet assay in fresh versus cryopreserved peripheral blood mononuclear cells obtained following dietary intervention, Mutagenesis 30 (2015) 29-35.

[187] J.L. Chang, G. Chen, J.W. Lampe, C.M. Ulrich, DNA damage and repair measurements from cryopreserved lymphocytes without cell culture-a reproducible assay for intervention studies, Environ. Mol. Mutagen. 47 (2006) 503-508.

[188] E.E. Visvardis, A.M. Tassiou, S.M. Piperakis, Study of DNA damage induction and repair capacity of fresh and cryopreserved lymphocytes exposed to $\mathrm{H} 2 \mathrm{O} 2$ and gamma-irradiation with the alkaline comet assay, Mutat. Res. 383 (1997) 71-80.
[189] M. Milić, I. Ožvald, I.V. Vrček, M.V. Lovrenčić, V. Oreščanin, S. Bonassi, E. Rojas Del Castillo, Alkaline comet assay results on fresh and one-year frozen whole blood in small volume without cryo-protection in a group of people with different health status, Mutat. Re 843 (2019) 3-10.

[190] D.P. Lovell, T. Omori, Statistical issues in the use of the comet assay, Mutagenesis 23 (2008) 171-182.

[191] M. Ceppi, S. Bonassi, M. Bruzzone, V. Fontana, Micronucleus assay: epidemiological and statistical issues, In: The micronucleus assay in toxicology. Editors: Fenech M., Knasmueller S., Nersesyan A. Eds. Royal Society of Chemistry, Cambridge, UK. In press.

[192] P. Armitage, G. Berry, J.N.S. Matthews, Statistical Methods in Medical Research, 4th edn, Blackwell Publishing Ltd, UK, 2002.

[193] W.S. Clevel, S.J. Devlin, Locally-weighted regression: an approach to regression analysis by local fitting. J. Am. Stat. Assoc. 83 (1988) 596-610.

[194] H. Goldstein, Multilevel Statistical Models, 3rd edn, Oxford University Press Inc., New York, 2003.

[195] P.A. Schulte, Biomarkers in epidemiology: scientific issues and ethical implications, Environ. Health Perspect. 98 (1992) 143-147.

[196] M. Neri, S. Bonassi, L.E. Knudsen, R.J. Sram, N. Holland, D. Ugolini, D.F. Merlo, Children's exposure to environmental pollutants and biomarkers of genetic damage. I. Overview and critical issues, Mutat. Res. 612 (2006) 1-13.

[197] D. Feretti, E. Ceretti, A. De Donno, M. Moretti, A. Carducci, S. Bonetta, M.R. Marrese, A. Bonetti, L. Covolo, F. Bagordo, M. Villarini, M. Verani, T. Schilirò, R. M. Limina, T. Grassi, S. Monarca, B. Casini, E. Carraro, C. Zani, G. Mazzoleni, R. Levaggi, U. Gelatti, MAPEC LIFE Study Group; MAPEC LIFE Study Group. Monitoring air pollution effects on children for supporting public health policy: the protocol of the prospective cohort MAPEC study, BMJ Open 4 (2014)e006096.

[198] L.D. Campbell, J.J. Astrin, Y. DeSouza, J. Giri, A.A. Patel, M. Rawley-Payne, A Rush, N. Sieffert, The 2018 revision of the ISBER best practices: summary of changes and the editorial team's development process, Biopreserv. Biobank. 16 (2018) 3-6.

[199] National Cancer Institute, National Institutes of Health U.S., Department of Health and Human Services Biorepositories and Biospecimen, Research Branch. NCI Best Practices for Biospecimen Resources. March 2016 (https:// biospecimens.cancer.gov/bestpractices/2016-NCIBestPractices.pdf).

[200] OECD Best Practice Guidelines for Biological Resource Centres, OECD, 2007. http://www.oecd.org/sti/biotech/38777417.pdf).

[201] World Medical Association Declaration of Helsinki, Ethical Principles for Medical Research Involving Human Subjects, (2013). https://www.wma.net policies-post/wma-declaration-of-helsinki-ethical-principles-for-medicalresearch-involving-human-subjects/).

[202] B. Dumez, K. Van Damme, L. Casteleyn, Research on ethics in two large human biomonitoring projects ECNIS and NewGeneris: a bottom up approach, Environ. Health 7 (2008) S7.

[203] E. Pernot, J. Hall, S. Baatout, M.A. Benotmane, E. Blanchardon, S. Bouffler, H. El Saghire, M. Gomolka, A. Guertler, M. Harms-Ringdahl, P. Jeggo, M. Kreuzer, D. Laurier, C. Lindholm, R. Mkacher, R. Quintens, K. Rothkamm, L. Sabatier, S. Tapio, F. de Vathaire, E. Cardis, Ionizing radiation biomarkers for potential use in epidemiological studies, Mutat. Res. 751 (2012) 258-286.

[204] V. Gallo, M. Egger, V. McCormack, P.B. Farmer, J.P. Ioannidis, M. KirschVolders, G. Matullo, D.H. Phillips, B. Schoket, U. Stromberg, R. Vermeulen, C. Wild, M. Porta, P. Vineis, STrengthening the reporting of observational studies in epidemiology: molecular epidemiology STROBE-ME. An extension of the STROBE statement, J. Epidemiol. Commun. Health 66 (2012) 844-854.

[205] A.D. Hernick, M.K. Brown, S.M. Pinney, F.M. Biro, K.M. Ball, R.L. Bornschein, Sharing unexpected biomarker results with study participants, Environ. Health Perspect. 119 (2011) 1-5.

[206] G.R. Wasson, A.P. McGlynn, H. McNulty, S.L. O’Reilly, V.J. McKelvey-Martin, G. McKerr, J.J. Strain, J. Scott, C.S. Downes, Global DNA and p53 region-specific hypomethylation in human colonic cells is induced by folate depletion and reversed by folate supplementation, J. Nutr. 136 (2006) 2748-2753.

[207] J.F. Wentzel, C. Gouws, C. Huysamen, Ev. Dyk, G. Koekemoer, P.J. Pretorius, Assessing the DNA methylation status of single cells with the comet assay, Anal. Biochem. 400 (2010) 190-194. 